\title{
Caspian sea-level changes during the last millennium: historical and geological evidence from the south Caspian Sea
}

\author{
A. Naderi Beni ${ }^{1}$, H. Lahijani ${ }^{2}$, R. Mousavi Harami ${ }^{1}$, K. Arpe ${ }^{3,4}$, S. A. G. Leroy ${ }^{4}$, N. Marriner ${ }^{5}$, M. Berberian ${ }^{6}$, \\ V. Andrieu-Ponel ${ }^{7}$, M. Djamali ${ }^{7}$, A. Mahboubi ${ }^{1}$, and P. J. Reimer ${ }^{8}$ \\ ${ }^{1}$ Geology Department, Faculty of Science, Ferdowsi University of Mashhad, Mashhad, Iran \\ ${ }^{2}$ Marine Geology Department, Iranian National Institute for Oceanography (INIO), Tehran, Iran \\ ${ }^{3}$ Max Planck Institute for Meteorology, Hamburg, Germany \\ ${ }^{4}$ Institute for the Environment, Brunel University, UB8 3PH Uxbridge, London, UK \\ ${ }^{5}$ Aix-Marseille Université, CNRS, CEREGE, UMR6635 - IRD, CEREGE, UMR161 - Collège de France, CEREGE, \\ 13545 Aix en Provence cedex 4, France \\ ${ }^{6}$ School of Mathematics, Science, and Technology, Ocean County College, Toms River, NJ 08754-2001, USA \\ ${ }^{7}$ Institut Méditerranéen de Biodiversité et d'Ecologie UMR7263 CNRS/Aix-Marseille Université - Europôle Méditerranéen \\ de l'Arbois - Pavillon Villemin - BP 80, 13545 Aix-en-Provence Cedex 04, France \\ ${ }^{8}$ School of Geography, Archaeology and Palaeoecology, Queen's University Belfast, Belfast, BT7 1NN, Northern Ireland, UK
}

Correspondence to: A. Naderi Beni (amnaderi@inio.ac.ir)

Received: 13 February 2013 - Published in Clim. Past Discuss.: 12 March 2013

Revised: 31 May 2013 - Accepted: 3 June 2013 - Published: 29 July 2013

\begin{abstract}
Historical literature may constitute a valuable source of information to reconstruct sea-level changes. Here, historical documents and geological records have been combined to reconstruct Caspian sea-level (CSL) changes during the last millennium. In addition to a comprehensive literature review, new data from two short sediment cores were obtained from the south-eastern Caspian coast to identify coastal change driven by water-level changes and to compare the results with other geological and historical findings. The overall results indicate a high-stand during the Little Ice Age, up to $-21 \mathrm{~m}$ (and extra rises due to manmade river avulsion), with a $-28 \mathrm{~m}$ low-stand during the Medieval Climate Anomaly, while presently the CSL stands at $-26.5 \mathrm{~m}$. A comparison of the CSL curve with other lake systems and proxy records suggests that the main sea-level oscillations are essentially paced by solar irradiance. Although the major controller of the long-term CSL changes is driven by climatological factors, the seismicity of the basin creates local changes in base level. These local base-level changes should be considered in any CSL reconstruction.
\end{abstract}

\section{Introduction}

The Caspian Sea (CS) has been characterized by substantial fluctuations during its geological lifetime (Varushchenko et al., 1987; Rychagov, 1997; Dolukhanov et al., 2010). It is believed that climate-induced changes are the main reason for the Caspian sea-level (CSL) fluctuations by influencing the hydrological budget of the sea (Arpe et al., 2000, 2012; Arpe and Leroy, 2007). According to the latitudinal extension of the CS and its watershed from dry low-latitude to temperate high-latitude climates (Fig. 1), and in view of the ongoing global warming, it provides a good opportunity to investigate the impacts of global climate variations on sea level and their socio-economic consequences (Gümilev, 1980; Dolukhanov et al., 2010). Historical and archaeological documents show that the CS has experienced frequent sea-level oscillations during the historical period. The CSL changes generated marked socio-economic impacts on the surrounding societies such as coastal property destruction, major tribal migrations and the rise/fall of civilizations (Gümilev, 1964, 1980; Létolle, 2000; Rekavandi et al., 2007). 
Historical documents may provide valuable information on Late Holocene geological events such as tsunamis (Dotsenko et al., 2002; Shah-hosseini et al., 2011), earthquakes (Ambraseys and Melville, 1982; Berberian, 1994; Berberian and Yeats, 1999), climatic variability (Brown, 2001; Okhravi and Djamali, 2003), and sea-level changes (Brückner, 1890; Varushchenko et al., 1987; Karpychev, 2001). The cultural evolution of human societies has mainly occurred during the Holocene that has, in turn, undergone significant environmental changes (Mayewski et al., 2004). Historical and archaeological evidence is therefore particularly pertinent in understanding human-environment interactions (Berberian et al., 2012).

Holocene Caspian sea-level (CSL) changes have been a key focus of geological research (Mamedov, 1997; Rychagov, 1997; Kroonenberg et al., 2000; Karpychev, 2001; Kazanc1 et al., 2004; Hoogendoorn et al., 2005; Lahijani et al., 2009; Dolukhanov et al., 2010; Leroy et al., 2011; Kakroodi et al., 2012; Naderi Beni et al., 2013), mostly based on the indirect interpretation of a variety of proxy data.

Direct instrumental measurements of the CSL fluctuations only began in the mid-nineteenth century (Leroy et al., 2006). Leroy et al. (2006) showed a good correlation between proxy-based interpretations and instrumental observations starting from 1871 in the Kārā-Bogāz Gol on the eastern coast of the Caspian Sea (CS) (Fig. 1). Due to the relatively short time frame of instrumental observations, palaeoenvironmental data contribute to extend the length of the sealevel records, which, in turn, may be accompanied by some uncertainties. One of the ways to decrease the uncertainties relating to the pre-instrumental geological data is to correlate the results with historical evidence recorded in ancient literature.

Although the history of civilization in the Caspian region dates back to more than $6000 \mathrm{yr}$ ago (Gilbert, 1978), little literature pre-dating the last millennium is available to compare and contrast with geological interpretations. In light of this, we here focus on the last millennium (the tenth to twentieth centuries $\mathrm{AD}$ ) to compare the historical events with related geological findings and to independently test the accuracy of palaeo-environmental data using new data from the south-east CS. Due to insufficient calibration datasets for the chronological data of the CS shells, we try to link the geological findings with historical observations and estimate the exact date of major CSL changes. Moreover, local irregularities such as vertical movements of the coasts, seiche and river avulsions might be partly underpinned by climatically driven sea-level changes. Therefore, historical evidence of the local irregularities has been investigated to show the impacts of the local sea-level changes on estimating the climatically driven CSL oscillations as a secondary objective.

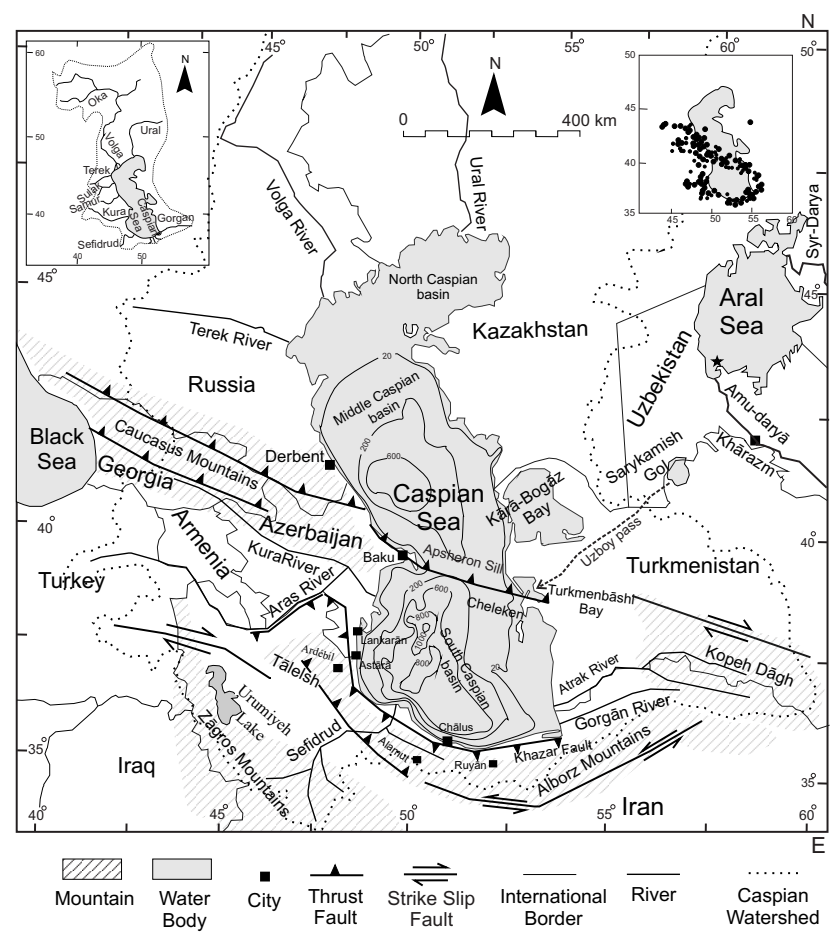

Fig. 1. Modern map of the Caspian Sea and its seaboard countries. The positions of the Aral Sea, the main rivers as well as the region's main faults are highlighted. The inset on the top left shows the whole watershed area of the Caspian Sea. The inset on the top right shows the recent earthquake epicentres of the region based on Jackson et al. (2002).

\section{Geographical setting}

\subsection{General view}

The CS has a surface area of $360000 \mathrm{~km}^{2}$ and $3.5 \mathrm{mil}-$ lion $\mathrm{km}^{2}$ of catchment area and is surrounded by five countries: Iran, Azerbaijan, Russia, Kazakhstan and Turkmenistan (Fig. 1). Due to its vast area, the lake is referred to as a "sea" in the literature. The land-locked nature of the sea has been known since ancient times. Ibn Hawqal (1988, p. 129) stated that: "the Sea is not linked to any other sea and the Atil River [the Volga] discharges into the sea and only this river is connected to the Constantine Sea [Black Sea] through one of its branches and if someone goes round the sea, one will return to the starting point".

The sea is saline and tide free (Ibn Hawqal, 1988, p. 129). The salinity of the sea is one third of that of the oceans and reaches up to 13 psu in the south-east. The CS separated from the open sea during the Pliocene (Varushchenko et al., 1987). Today the CSL is around $-26.5 \mathrm{~m}$ below mean sea level. Owing to its land-locked nature, the CS has fluctuated repeatedly during its geological lifetime. 


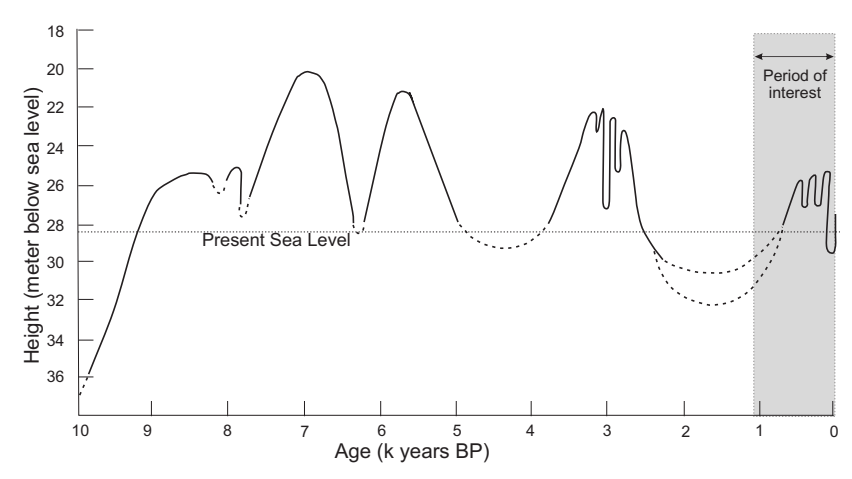

Fig. 2. Caspian sea-level changes during the last $10000 \mathrm{yr}$, in uncalibrated radiocarbon ages (Rychagov, 1997). The study period of the present investigation is denoted by the grey shading.

\subsection{Caspian sea-level changes}

The CS is known for its pronounced sea-level changes at various timescales (Kazanc1 et al., 2004). During the latest Pleistocene, sea level rose up to $\sim 50 \mathrm{~m}$ (Khvalynian Transgression) (Mamedov, 1997) and then dropped to at least $-50 \mathrm{~m}$ at the beginning of the Holocene (Mangyshlak Regression) (Dolukhanov et al., 2010). CSL oscillations during the Holocene have been estimated by Rychagov (1997, Fig. 2). Apart from these two extensive changes in sea level, at least eight minor oscillations have been recognized for the last $4000 \mathrm{yr}$ (Mamedov, 1997). During the past $\sim 1000 \mathrm{yr}$, the CS has experienced two major sea-level changes associated with the Medieval Climate Anomaly (MCA: 950-1250) and the Little Ice Age (LIA: 1350-1850) (Ruddiman, 2008). According to Kroonenberg et al. (2007) and Leroy et al. (2011), during the MCA the CSL dropped and then during the LIA the sea level rose. CSL changes continued to fluctuate during the nineteenth and the twentieth centuries. The sea level fell $\sim 3 \mathrm{~m}$ from 1929 to 1978 , and was followed by a rise of $\sim 2.7 \mathrm{~m}$ from 1978 to 1995 , at a rate one hundred times faster than the present global sea-level rise (Kroonenberg et al., 2000).

In addition to long-term CSL changes, on several occasions, abnormal, alternate rising and lowering of the sea level have been reported in old manuscripts and the recent instrumental record that could be recorded by some geo-scientists as long-term CSL changes. Some unexpected sudden sealevel fluctuations were possibly related to large-magnitude inland or sea-based earthquakes (Shilo and Krivoshey, 1989; Rodkin, 1992a, b; Ozyavas et al., 2010).

\subsection{Geological and seismotectonic setting}

The CS intercontinental basin is located on old platforms to the north and the young orogens to the south. The northern part of the depression is located on the Turān in the NE and the Scythian aseismic platforms in the NW. The southern part of the sea, the South Caspian deep basin is surrounded by the
Late Miocene-Pliocene uplifted and overthrust active orogens of the Caucasus and Tālesh (SW), the Alborz (S), and the Kopeh Dāgh (also known as Kopet Dāg) (SE) (Fig. 1). Lithologically, Kopeh Dāgh comprises sedimentary deposits (mainly limestone), while the Alborz contains igneous and metamorphic rocks (Berberian and King, 1981).

The South Caspian deep basin is a relatively rigid aseismic stable block floored by a trapped, modified oceanic crust surrounded by overthrust continental crust (Gegelyantz et al., 1958; Berberian, 1983; Priestley et al., 1994; Mangino and Priestley, 1998). It is being subducted beneath the North Caspian (Fig. 1) along the Āpshehron-Bālkhān Sill (Knapp et al., 2004).

Seismological analysis of the central and southern parts of the CS has shown that the most probable area of seismic seiche generation is between the Āpsheron-Bālkhān Sill and Derbent in the central Caspian basin (Dotsenko et al., 2002) (Fig. 1). Berberian and Walker (2010) showed that the inland earthquakes on the southern and western coasts could provide some irregularities in the CSL (see below).

The south Caspian coastal plain lies on the footwall of the Khazar reverse fault (Fig. 1) and is in subsiding mode while the rate of relative vertical movement for the coastal plain is negligible for the last millennium (Djamour et al., 2010).

\subsection{Hydrology of the Caspian Sea}

The hydrological balance between input and output of the sea controls the sea level (Kroonenberg et al., 2000; Arpe et al., 2012). The sea's inputs are mainly governed by rivers, discharging from the north, west and south as well as precipitation over the sea. The output is mainly controlled by evaporation over the sea and the watershed (Arpe and Leroy, 2007; Arpe et al., 2012). This means that the sea-level oscillations are strongly dependent on climatic variations (Kroonenberg et al., 2000), at least as long as no major changes are taking place in the size of the hydrographical basin. The surface area of the Caspian catchment basin is around ten times greater than the CS surface itself (Fig. 1 inset). The latitudinal extension of the sea results in climate variations over the basin from sub-tropical in the southwest to desertic in the east and northeast (Leroy et al., 2011).

The Volga River is the largest river of the CS, discharging from the north (Fig. 1), and presently provides $\sim 80 \%$ of all river influx to the sea.

al-Maqdisī (1982, p. 544) in 985 AD described the southern coast of the CS with frequent rivers flowing from the Tus (southern Kopeh Dāgh), Tabarestān and Daylam (the Alborz) Mountains (Fig. 1). Although most of the Iranian rivers originate from the northern flank of the Alborz Mountains, the Sefidrud originates further, in the Zāgros and the Alborz Mountains. The Gorgān and Atrak Rivers in the east have headwaters in the Kopeh Dāgh (Lahijani et al., 2009) (Fig. 1). The Sefidrud and the Gorgān River have developed large deltas along the Caspian coast due to considerable sediment supply, 


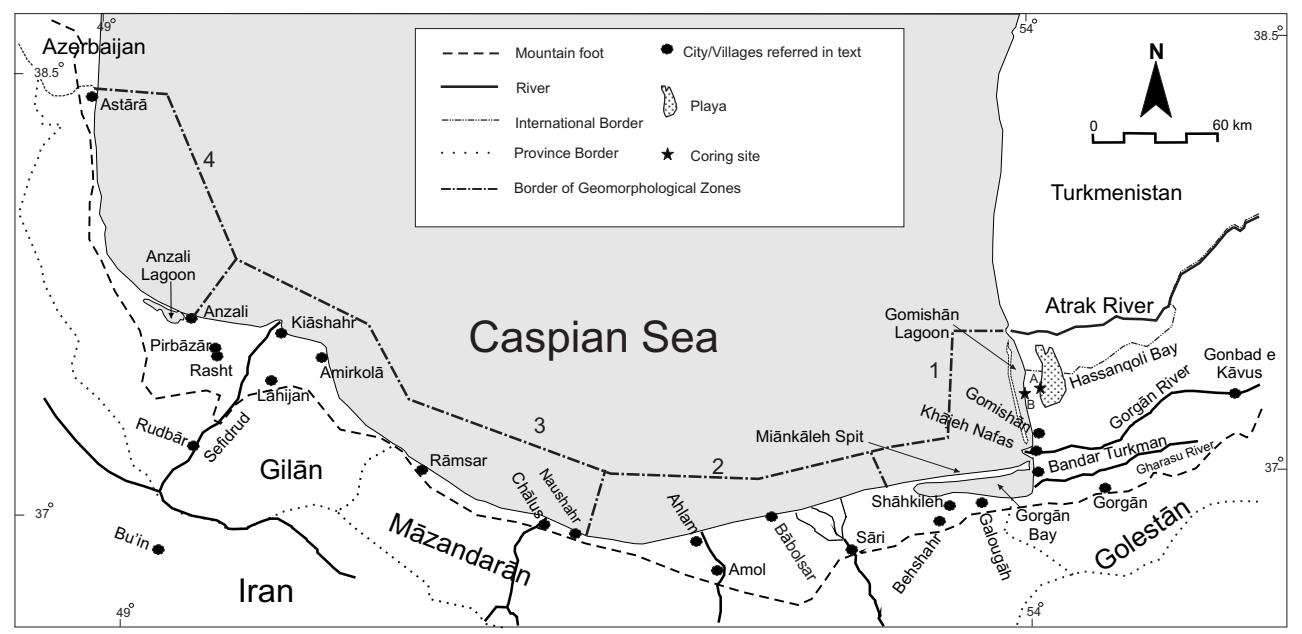

Fig. 3. The Caspian coast of Iran, with its prominent coastal landforms and major rivers. The cities mentioned in this paper are marked on the map. The morphological zones of the south Caspian coast (Voropaev et al., 1998) are highlighted. 1: Coasts with gentle slopes on the beach and in the nearshore zone. 2: Coasts with gentle slopes on the beach and steep slopes in the nearshore zone. 3: Coasts with steep slopes on the beach and nearshore zone. 4: Coasts with steep slopes on the beach and gentle slopes in the nearshore zone. Core locations are indicated by the star symbol.

and have repeatedly changed their courses (Kousari, 1986; Voropaev et al., 1998). The largest input of sediments in the whole of the CS comes, however, from the Sefidrud (Lahijani et al., 2008). According to Leroy et al. (2007), the Aral Sea and CS were connected episodically during the last millennia through the Uzboy pass (Fig. 1) due to sea level fluctuations, tectonic events or human intervention. The Uzboy River received water from low latitudes via Amu-darya and discharged into the Caspian Sea in Turkmenbāshi Bay around 2200 to $1700 \mathrm{yr}$ BP (Leroy et al., 2007) (Fig. 1).

The winds over the CS produce prevailing southward longshore currents on the west and east coasts, and eastward currents along the Iranian shoreline (Lahijani et al., 2009; Ibrayev et al., 2010).

\subsection{Morphology of the Iranian Caspian coast}

The Caspian coastline of Iran stretches over $800 \mathrm{~km}$ along the three Iranian provinces of Gilān in the west, Māzandarān in the middle and Golestān in the east (Fig. 3). According to Voropaev et al. (1998), the Iranian Caspian coast can be classified into four morphological zones based on beach and nearshore gradients (Fig. 3). This classification clearly shows that the southeast corner of the CS has a gentler slope offshore and on land, and will, therefore, be more sensitive to small changes in sea level.

The Iranian coast of the CS consists of different landforms and geomorphological features including bays, spits, lagoons and deltas, mainly developed during the Quaternary (Kazanc1 et al., 2004). Amongst the landforms, the Anzali Lagoon and the Sefidrud Delta in the west and the Gorgān Bay, the Gorgān Delta, as well as the Gomishān Lagoon and the Hassanqoli Bay in the east are the most prominent ones
(Fig. 3), whose formation and evolution are largely driven by the CSL changes coupled with the hydrodynamic regime (Kroonenberg et al., 2007; Kakroodi et al., 2012; Naderi Beni et al., 2013).

\section{Material and methods}

Two short cores (two meters in length and five $\mathrm{cm}$ in diameter) were obtained from the southeast of the CS, in front of the Hassanqoli Bay using a vibracorer (Fig. 3). They were taken from the morphological zone 1 of Voropaev et al. (1998), which is the most sensitive area to sea-level changes. The cores were analysed sedimentologically to correlate with historical documents as well as other geological findings.

The elevation of the coring sites was measured using an Ashtech Mobile Mapper 100. The magnetic susceptibility (MS) of the core samples was measured using a MS2C corelogging scanner from Bartington. The diameter of the susceptibility meter loop was $10 \mathrm{~cm}$ and the progression step was $2 \mathrm{~cm}$. The sensitivity of the meter was about $2 \times 10^{-6}$ SI.

Core samples were split and sub-sampled at the laboratory of the Iranian National Institute for Oceanography (INIO) for sedimentological analysis. A Nabertherm P330 furnace was used for loss-on-ignition to measure organic matter and carbonate content based on the methods outlined in Heiri et al. (2001). Grain-size measurements were made using a Horiba Laser Scattering Particle Size Distribution Analyzer LA-950. 
Table 1. Geological findings on the Caspian sea-level (CSL) changes in the Late Holocene. The sea level position is inserted where the data are available.

\begin{tabular}{llrrl}
\hline Location & Event & Age (AD) & CSL & Reference \\
\hline South CS & Sea-level rise and spit development & 1042 & -24 & Lahijani et al. (2009) \\
South CS & Sea level rises to $-24 \mathrm{~m}$ & $1289-1403$ & -24 & Kakroodi et al. (2012) \\
South CS & Relative sea level rise & $1311-1445$ & - & Naderi Beni et al. (2013) \\
South CS & Sea level rises to $-24 \mathrm{~m}$ & $1335-1446$ & -24 & Kakroodi et al. (2012) \\
South CS & Inundation of Gorgān Wall & $1344-1460$ & -22 & Rekavandi et al. (2007) \\
West CS & Sea-level rise and barrier formation & $1350-1640$ & -24 & Kroonenberg et al. (2007) \\
South CS & Relative sea-level rise & $1408-1514$ & - & Naderi Beni et al. (2013) \\
South CS & Sea-level rise & 1460 & -25 & Lahijani et al. (2009) \\
West CS & Sea-level rise and barrier formation & $1590-1710$ & -24 & Kroonenberg et al. (2007) \\
South CS & Sefidrud avulsion & 1600 & - & Lahijani et al. (2009) \\
West CS & Kura River diverted to Qezel Agac Bay & $1600-1800$ & - & Hoogendoorn et al. (2005) \\
South CS & Age of the core base in Amirkolā & 1620 & - & Leroy et al. (2011) \\
South CS & Relative sea-level rise & $1696-1726$ & - & Naderi Beni et al. (2013) \\
South CS & Anzali Spit broken into barrier islands & $1700-1830$ & - & Leroy et al. (2011b) \\
West CS & Development of new Kura Delta & 1800 & - & Hoogendoorn et al. (2005) \\
East CS & Sea-level rise & 1830 & -25.5 & Leroy et al. (2006) \\
\hline
\end{tabular}

Fossil content was identified to aid in characterizing the past depositional environments based on the atlas of the invertebrates of the CS (Birstein et al., 1968).

Two articulated bivalve shells of Cerastoderma lamarcki, an indicator of marine environment, were selected and sent to Poznan Radiocarbon Laboratory for ${ }^{14} \mathrm{C}$ dating.

Calendar ages were obtained from the CALIB Rev 6.1.1 software (Stuiver and Reimer, 1993) based on the Marine09 curve (Reimer et al., 2009) with $\Delta \mathrm{R}=26 \pm 69$ ${ }^{14} \mathrm{Cyr}$ (Kuzmin et al., 2007; Olsson, 1980) as well as based on the IntCal09 curve (Reimer et al., 2009) with $\mathrm{RE}=407 \pm 27{ }^{14} \mathrm{C}$ yr to compare the results and correlate them with historical findings to get an estimate of the reservoir effect of the sea.

Several historical documents were studied, mainly in the library of the Ferdowsi University of Mashhad, and related geographical names and positions were extracted based on the "Historical Geography of Cities" (Nahchiri, 1999). We have used the most reliable literature sources covering the last millennium. Historical observations of the CS environments were gathered to compare and contrast with geological records for the same period.

Note that in this study the dates are given in AD, unless otherwise stated. The Persian geographic names and other Persian words are written as they are pronounced and were originally written, with direct and simplified transliteration from Persian to English. Diacritical marks and special characters are used to differentiate the vowel "A" [short; e.g. ant]

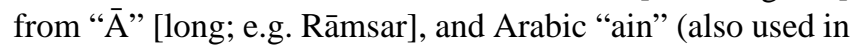
Persian) as "'A" [e.g. "Abbās]. Elevations are above or below the present mean sea level. Rud and Darya mean river and Dagh means mountains.

\section{Results and interpretation}

\subsection{Geological findings}

The CSL changes and their impact on coastal evolution have been investigated by several researchers e.g. Kroonenberg et al. (2000, 2007), Lahijani et al. (2009), Kazanci et al. (2004), Leroy et al. (2011), Kakroodi et al. (2012) and Naderi Beni et al. (2013). The results of the geological investigations on the CSL are summarized in Table 1.

In this study we focused on two short cores from the southeastern flank of the CS to compare the results with other geological findings as well as historical evidence.

The lithology of the cores shows a succession of terrestrial (fluviodeltaic in Kakroodi et al., 2012) and marine environments during the last millennium (Fig. 4). Generally, the marine facies comprise finer-grained materials compared to terrestrial deposits based on the modal grain size and contain marine bivalve fossils of Cerastoderma lamarcki. The terrestrial deposits constitute alternations of thin layers of fine sand, silt and clay, without any fossil content but containing gypsum minerals that are concentrated in some horizons. The presence of gypsum minerals in terrestrial sediments could be related to the flat topography of the region and warm climatic conditions that lead to water evaporation during dry seasons. Sea-level rise is indicated by a change from the terrestrial facies to marine facies. In the marine facies, organic matter and carbonate contents tend to increase due to higher organic activity in shallow marine environment and presence of calcareous shell-bearing organisms (Fig. 4).

The magnetic susceptibility results show lower values in terrestrial deposits (Fig. 4), which could be related to the provenance of the grains or the increase in evaporative 


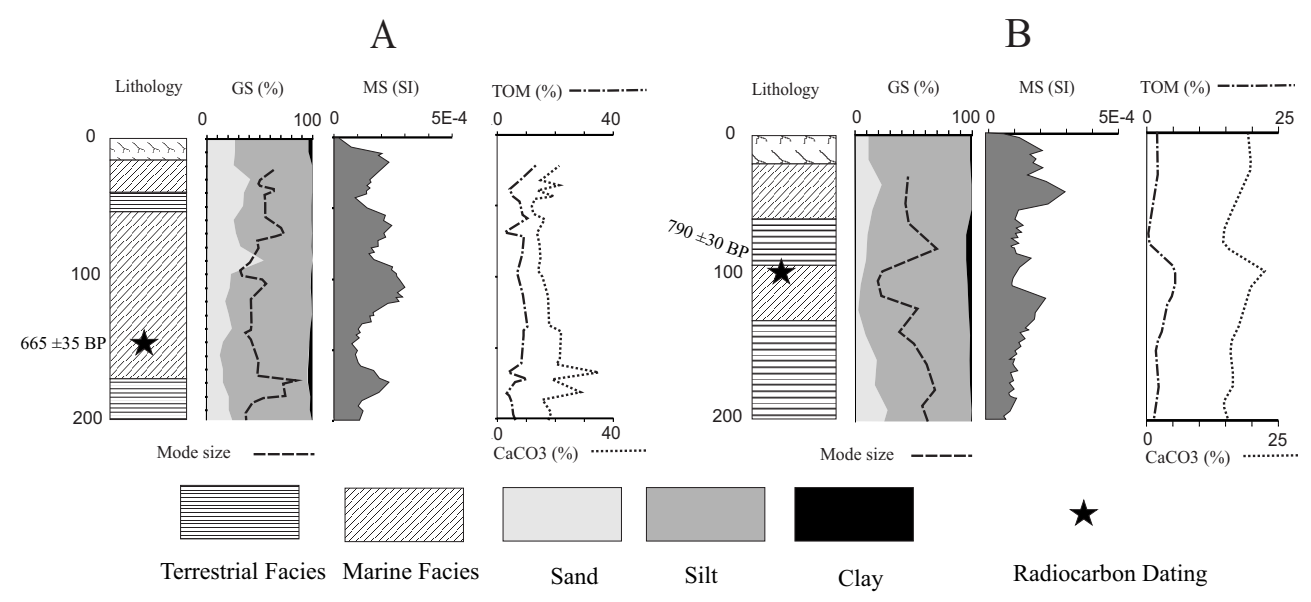

Fig. 4. Lithology of two cores taken near Hassanqoli Bay in the southeast of the Caspian Sea. The position of the cores is presented in Fig. 3. The stars denote the dated horizons and the corresponding radiocarbon ages (BP). GS: Grain Size; MS: Magnetic Susceptibility; TOM: Total Organic Matter. The vertical axis is depth in $\mathrm{cm}$.

minerals. Magnetic susceptibility measures the magnetisability of a material (Dearing, 1999). In sediments, it depends largely on the mineralogy of materials particularly to $\mathrm{Fe}$ bearing minerals as well as the grain size. According to increasing bio-chemical activities in marine environments, which are reflected in the marine deposits, and concentration of Fe-bearing minerals in detrital deposits, which are common in the terrestrial deposits, lower values of magnetic susceptibility are expected of the marine facies in the sediment cores, while the marine facies show higher values of magnetic susceptibility in the cores. This apparent contradiction could be answered by paying attention to the source of the sediments.

The feeding watercourses have their headwaters in the Kopeh Dāgh that is mantled in calcareous deposits (Berberian and King, 1981). The higher magnetic susceptibility values in the marine facies could be linked to the presence of paramagnetic minerals, e.g. muscovite, flogopite and biotite, which are transported by longshore currents from the southern coast of the CS (Ibrayev et al., 2010). The paramagnetic components of the southern coast deposits are provided by igneous and metamorphic rock outcrops of the Alborz Mountains (Lahijani and Tavakoli, 2012).

According to the presence of some brackish water gastropods such as Theodoxus palassii, as well as Charophytes that coexist with marine gastropods Horatia marina and Pyrgohydrobia sp. and the marine bivalve Cerastoderma lamarcki (Birstein et al., 1968), it seems that the marine facies could represent a shallow marine environment and/or an open lagoon that was influenced by fresh-water input. The formation of barrier-lagoon complexes during rapid sea-level rise has been reported by Kroonenberg et al. (2007), Lahijani et al. (2009) and Naderi Beni et al. (2013) in different parts of the Caspian coast and, therefore, it is more probable to link the marine facies to an open lagoon environment which was influenced by fresh water input.

\subsection{Radiocarbon dating}

The age of the oldest marine facies of cores A and B (Fig. 4) is dependent on the reservoir effect (RE), which has been estimated differently in various studies: from 290 to $400 \mathrm{yr}$ (Leroy et al., 2011). For example, some of the reported RE ages are: 345 to $384{ }^{14} \mathrm{C}$ yr in Karpychev (1993), $290{ }^{14} \mathrm{C}$ yr in Kroonenberg et al. (2007), 390-440 ${ }^{14} \mathrm{C}$ yr in Kuzmin et al. (2007), and $383{ }^{14} \mathrm{C}$ yr in Leroy et al. (2007). Although almost all of the chronological data are coincident with the LIA in the North Atlantic Ocean and already recorded in the CS by a high-stand (Leroy et al., 2011 in Gilān, and Kakroodi et al., 2012 in Golestān), they could be linked to different sealevel rise episodes between the fifteenth and the nineteenth centuries, depending on the reservoir age used in calibrating the radiocarbon dates.

The chronology was based on shell dating because: (1) the shells are the most abundant material in the cores for dating; (2) by choosing articulated shells, the risk of transporting and reworking is minimal; (3) of the possibility to compare the dating results with previous works such as Rychagov (1997), Karpychev (1998, 2001), Lahijani et al. (2009), Leroy et al. $(2011,2013)$ and other researchers who mostly dated the sea-level changes based on shell chronology; finally (4) of the possibility to correct for the $\mathrm{RE}$ by using the Marine 09 curve with an appropriate regional correction $\triangle \mathrm{R}$ when calibrating the age of marine samples. Since the CS is not connected to the global ocean and turns over annually, it is unclear whether it is more appropriate to use the atmospheric calibration curve (IntCal09) with the sample age corrected by subtracting RE and including the 


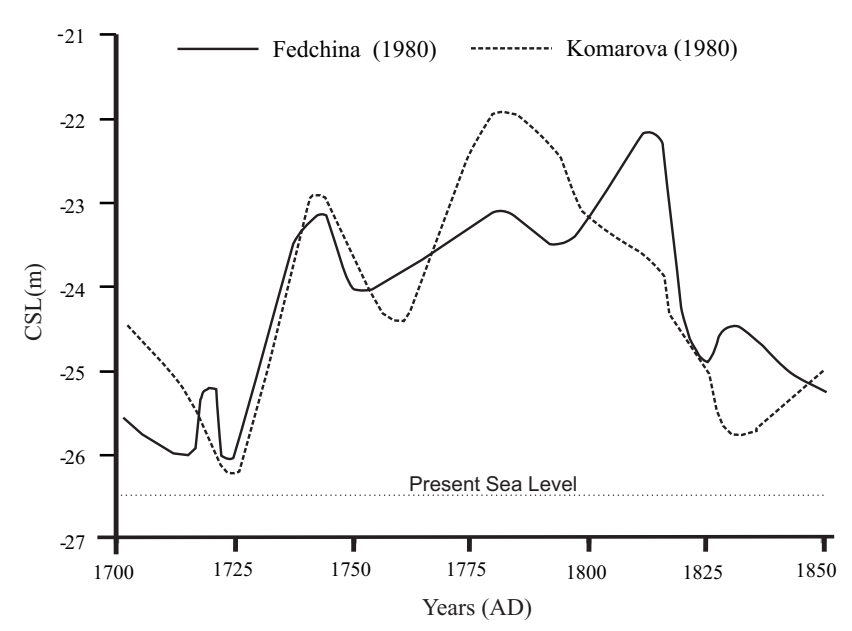

Fig. 5. The Caspian sea-level (CSL) changes during the eighteenth century and first half of the nineteenth century (Fedchina, 1980) and the sea-level curve from Komarova (1980) based on Russian cartographic maps.

uncertainty in RE in the error, so both approaches are used here and compared (Table 2).

According to the elevation of the coring site (Table 2), it seems that sea level in dating horizons reached -26.75 and $-25.8 \mathrm{~m}$ for cores A and B, respectively, as the subsidence of the region has been negligible during the last millennium.

\subsection{Historical evidence}

The CSL variability before the instrumental observations (prior to 1850) was investigated by Brückner (1890) on the CS coast. He used a wide range of observational evidence, e.g. travel descriptions, navigation maps, and paintings to garner data on CSL changes. Typical examples were walls along the shore with markings of sea levels, reports about buildings that disappeared under the water, and islands that emerged or disappeared. The results of Brückner (1890) are summarized in Table 3.

Fedchina (1980) used the Russian cartographic data from 1556 to 1925 to reconstruct a CSL curve. The same method was followed by Komarova (1980) for the time period between 1700 to 1850. The results of Fedchina (1980) and Komarova (1980) are summarized for the period 1700 to 1850 in Fig. 5. In spite of some differences between their analyses, the results generally show a good agreement in the CSL changes during the time period with high-stands up to $-22 \mathrm{~m}$ (Fig. 5).

Varushchenko et al. (1987) used a wide range of historical, archaeological and geological evidence to reconstruct CSL changes for the last $2400 \mathrm{yr}$. Many historical and archaeological documents used by Varushchenko et al. (1987) for the last millennium are the same as those that Brückner (1890) and Komarova (1980) considered in their work (Table 4).

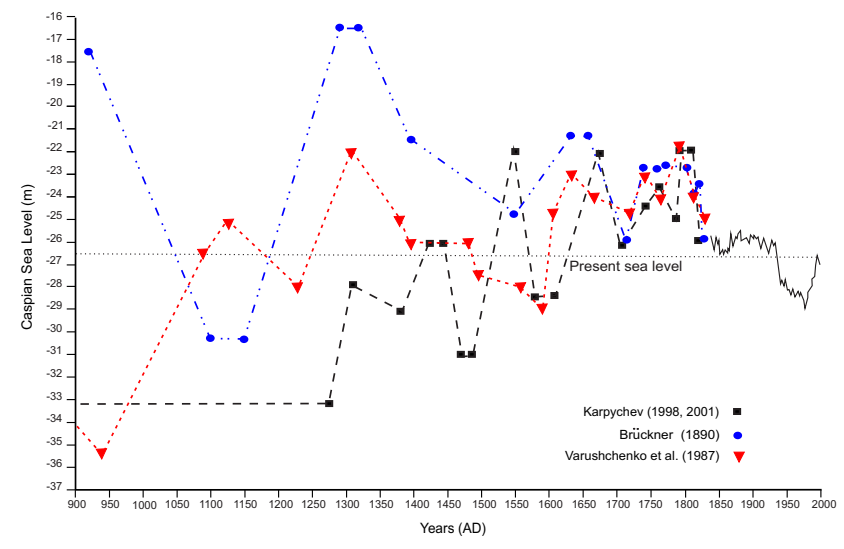

Fig. 6. The Caspian sea-level curve based on Brückner (1890), Varushchenko et al. (1987) and Karpychev (1998, 2001). The dashed lines connecting the filled symbols are interpolations. The continuous line from 1850 to 2000 shows the instrumental observations. A -26.5 line, the CSL in 1995 , was added as a reference level to compare the different levels over the past millennium. The Medieval Climate Anomaly (MCA) and the Little Ice Age (LIA) are indicated by shaded boxes.

However, their results have many differences, particularly in the early centuries of the last millennium.

Lithological evidence from coring along the Caspian coastline was investigated by Karpychev (1998) and combined with historical information (Karpychev, 2001) for layers of pebbles, for instance, which are an indication for shores at that level and for which the age was determined by radiocarbon dating. The results of Karpychev $(1998,2001)$ are summarized in Table 5.

Based on the results of Tables 3, 4 and 5, the CSL curve has been plotted from the tenth to the twentieth centuries (Fig. 6).

The Iranian literary texts are especially rich in statements pertinent to understanding the historical geography and geological events of the Iranian Plateau and its neighbouring regions (e.g. Berberian, 1994; Okhravi and Djamali, 2003). Here, we present historical literature related mainly to the south CS to elucidate evidence of CSL changes during the last millennium split into three periods: the ninth to fourteenth centuries, the sixteenth and seventeenth centuries, and the eighteenth to twentieth centuries.

\subsubsection{The Caspian Sea level during the ninth to fourteenth centuries}

One of the most important cities of the Caspian coasts in ancient times was Ābeskun/Ābaskun (Figs. 7, 8), which apparently disappeared in the early fourteenth century due to sea-level rise (Mostowfi, 1999, p. 239). Nedjati (in Gümilev, 1980) described how the port of Ābeskun was flooded and swallowed up by the sea in 1304 in agreement with other reports of a CSL high-stand (Tables 3 and 4). al-Istakhri 
Table 2. AMS radiocarbon dating of the sediment cores. The $2 \sigma(95.4 \%)$ calibrated age ranges are based on the Marine 09 curve with an average $\Delta R=26 \pm 69{ }^{14} \mathrm{C}$ yr (Kuzmin et al., 2007; Olsson, 1980) and on IntCal09 curve with a reservoir effect (RE) of $407 \pm 27{ }^{14} \mathrm{C}$ yr subtracted with the probabilities shown in parentheses. For core location, see Fig. 3.

\begin{tabular}{|c|c|c|c|c|c|c|c|c|}
\hline Core No. & Lab. No & $\begin{array}{l}\text { Elevation } \\
\text { (m) }\end{array}$ & $\begin{array}{l}\text { Depth of } \\
\text { sampling } \\
\text { (cm) }\end{array}$ & $\begin{array}{l}\text { Type of } \\
\text { material }\end{array}$ & $\begin{array}{l}\text { Radiocarbon } \\
\text { Age (yr BP) }\end{array}$ & $\begin{array}{l}\text { Calibrated } \\
\text { Age }(\mathrm{yr} \text { AD) } \\
\text { for } 2 \sigma \text { range } \\
\text { Marine } 09, \\
\Delta \mathrm{R}=26 \pm 69^{*}\end{array}$ & $\begin{array}{l}\text { Calibrated } \\
\text { Age }(\mathrm{yr} \mathrm{AD}) \\
\text { for } 2 \sigma \text { range } \\
\text { IntCal09, } \\
\mathrm{RE}=407 \pm 27^{*}\end{array}$ & $\begin{array}{l}\text { Calibrated } \\
\text { Age (yr AD) } \\
\text { for } 2 \sigma \text { range } \\
\text { IntCal09, } \\
\text { RE }=383^{* *}\end{array}$ \\
\hline A & Poz-51062 & -25.3 & 145 & $\begin{array}{l}\text { Articulated } \\
\text { bivalve }\end{array}$ & $665 \pm 35$ & $\begin{array}{l}1496-1872 \\
\text { (1) }\end{array}$ & $\begin{array}{l}1490-1682 \\
(0.8) \\
1737-1803 \\
(0.2)\end{array}$ & $\begin{array}{l}1486-1604 \\
(0.68) \\
1607-1664 \\
(0.32)\end{array}$ \\
\hline B & Poz-51060 & -24.8 & 100 & $\begin{array}{l}\text { Articulated } \\
\text { bivalve }\end{array}$ & $790 \pm 30$ & $\begin{array}{l}1437-1681 \\
\text { (1) }\end{array}$ & $\begin{array}{l}1440-1529 \\
(0.6)- \\
1543-1634 \\
(0.4)\end{array}$ & $\begin{array}{l}1433-1521 \\
(0.86) \\
1591-1621 \\
(0.34)\end{array}$ \\
\hline
\end{tabular}

* Average weighted mean RE, $\Delta \mathrm{R}$, and standard deviation for five known age data points in the Caspian Sea (Kuzmin et al., 2007; Olsson, 1980). Cal age ranges with gaps of 10 years or less have been combined for IntCal09 calibrations. Relative probability is given in parentheses. ** RE $=383$ (Leroy et al., 2007 ).

Table 3. Dates, type of historical evidence and the Caspian sea-level summary from the tenth to nineteenth centuries (Brückner, 1890).

\begin{tabular}{llr}
\hline Year & Information & $\begin{array}{r}\text { Caspian sea- } \\
\text { level (m) }\end{array}$ \\
\hline $915-921$ & 6 projections in the wall at the fort in Derbent reached into the sea & -17.4 \\
$1100-1150$ & Building of a caravanserai near Baku which was submerged later & $<-30.4$ \\
$1306-1320$ & Tomb of Sheik Zahed in Lankarān in danger of flooding & $<-16.0$ \\
1400 & Mosque in Baku (but some doubts) & -21.4 \\
1556 & Navigation at Volga exit to Caspian Sea (less reliable) & -24.7 \\
1638 & Markings on fort wall in Derbent & -21.3 \\
$1715-1720$ & Many sources 1715 lowest level & -25.9 \\
$1735-1743$ & Many sources 1723 to 1743 rise by 2.4 m & -22.7 \\
$1754-1766$ & Many sources & -22.75 \\
$1767-1780$ & Many sources & -22.65 \\
1805 & Many sources & -22.7 \\
1816 & Many sources & -23.8 \\
1830 & Many sources & -25.8 \\
$1843-1846$ & Many sources & -26.7 \\
1847 & Many sources & -26.0 \\
$1851-1855$ & Many sources & -26.4 \\
$1856-1860$ & Many sources & -26.47 \\
$1861-1865$ & Many sources & -26.39 \\
$1866-1870$ & Many sources & -26.01 \\
$1871-1875$ & Many sources & -26.03 \\
$1876-1878$ & Many sources & -25.66 \\
\hline
\end{tabular}

(1961, p. 173) in the tenth century described Ābeskun as the best port in the CS. The tenth century historians and geographers such as al-Mas' ūdī (2012, p. 25/2), al-Istakhri (1961, p. 173) and Ibn Hawqal (1988) reported Ābeskun as a port, while the later geographers like Jovayni (1911, p. 115/2) in the thirteenth century and Banāketi (1969, p. 240) and Mostowfi (1999, p. 239; possibly compiled older treatises) in the fourteenth century described it as an island. According to the dates of the descriptions, it seems that an important change in the CSL occurred during this time period. When sea level was relatively lower during the ninth and tenth centuries, Ābeskun lay on the shoreline, whereas when the sea level rose in the thirteenth and fourteenth centuries it was surrounded and then flooded by the sea.

Barthold (1984) speculated that the location of Ābeskun is consistent with the present Gomishān, which lies at about $-23.5 \mathrm{~m}$ elevation, in line with the level by Karpychev (1998, 2001) in 1304 (Table 5). Gümilev (1964) assumed that the CSL was at $-33 \mathrm{~m}$ in the tenth century and rose to $-28.5 \mathrm{~m}$ in the eleventh century based on al-Istakhri's observation 
Table 4. Dates, type of historical and geological evidence and the Caspian sea-level summary from the tenth to nineteenth centuries (Varushchenko et al., 1987).

\begin{tabular}{|c|c|c|c|}
\hline $\begin{array}{l}\text { Historical } \\
\text { Record (AD) }\end{array}$ & $\begin{array}{l}\text { Dating } \\
\text { (BP) }\end{array}$ & CSL (m) & Information \\
\hline 8 th to 10 th centuries & - & -28 to -30 & Historical documents of al-Istakhri (951) and geomorphological data of Derbent Wall \\
\hline 934-945 - n & - & -35 to -36 & Derbent Wall was a mile in the sea (al-Mas' ūdī, 947) \\
\hline- & $860 \pm 40$ & $-26(-25 ?)$ & ${ }^{14} \mathrm{C}$ dating on peat layer, Balakhan, $75 \mathrm{~km}$ east of Turkmenbāshi Bay \\
\hline 11 th to 13 th century & & -31.7 to -34 & Cultural horizon of Bayandovan city near Kura Delta has minimum level of $-29.7 \mathrm{~m}$ \\
\hline $1234-1235$ & - & -29.2 to -27 & Construction of Cārvānsarāi in Baku at a level of -27.2 , sea level is unknown \\
\hline 14th century & - & -27 to -28 & Position of tomb of Sheikh Zahed in Lankarān (1306-1307) \\
\hline 14th century & - & -22.5 & Footnotes of Marin Sanudo map: every year the sea level increases about a Ladon (?) \\
\hline 14th century & - & -26 & The Chechen Island with $-24 \mathrm{~m}$ elevation was reported in Genuetzev map in the late 14 th century \\
\hline 14th century & - & -26 to -25 & Many fortifies submerged in the city of Baku and the sea was near the mosque \\
\hline- & $510 \pm 40$ & -26 & ${ }^{14} \mathrm{C}$, Balakhan, $75 \mathrm{~km}$ east of Turkmenbāshi Bay \\
\hline $1474-1478$ & - & -27 to -28 & Barbaro reported Derbent Wall emerged \\
\hline 1604 & - & -25.3 & $\begin{array}{l}\text { Terek city was about } 7.4 \mathrm{~km} \text { from the river mouth and the Chechen Island with }-23.8 \mathrm{~m} \text { elevation } \\
\text { was } 52 \mathrm{~km} \text { from the coastline. }\end{array}$ \\
\hline $1606-1629$ & - & -23 to -24 & Derbent fort was constructed by Shāh-Abbās Safavid \\
\hline 1623 & - & - & F. A. Kotov report on Derbent fort built by Shāh-Abbās \\
\hline 1623 & - & -25 to -24.5 & Terek city was about 35 to $55 \mathrm{~km}$ from shoreline \\
\hline 1668 & - & -24 & Visiting the Derbent Wall by Aliyāri who did not mention the wall was in the sea \\
\hline 1668 & - & -24 & The Terek city was displaced due to flooding \\
\hline $1715-1717$ & - & -25.5 & Map of Bekovich \& Cherkasski \\
\hline 1720 & - & -25.6 & The first Russian cartographic map of V. Soymonov \\
\hline $1726-1731$ & - & -25.5 to -26.2 & Based on Soymonov map \\
\hline 1745 & - & -23 & Based on Vodrov map \\
\hline $1764-1765$ & - & -24 to -24.5 & Based on a map of Tolmachev-Ladyzhensky \\
\hline $1781-1782$ & - & -22 & Based on Voynovich map \\
\hline 1796 & - & -22.7 to -23 & A map with anonymous cartographer \\
\hline $1809-1817$ & - & -23.7 to -24 & Map of A.E. Kolodkin \\
\hline 1820 & - & -24 to -24.2 & A report from a Russian newspaper \\
\hline $1819-1821$ & - & -24.5 & Information from Moraviev \\
\hline $1825-1826$ & - & -25 & CSL reconstructed based on Berg (1934) \\
\hline
\end{tabular}

in Derbent, in present-day Dagestan, Russia (Fig. 1). Also, Varushchenko et al. (1987) reported about such a rise but from -35 to $-33 \mathrm{~m}$. The eleventh century sea-level rise reduced the area of the Volga Delta and endangered the Kingdom of Khazaria due to the reduction of its farmlands (Gümilev, 1964).

Ibn Hawqal (1988, p. 125) described Ābeskun's air as malodorous and full of mosquitoes, which could be linked to the presence of marshlands and/or lagoons. The town was populous and repeatedly invaded between 880 and 913 by Russian tribes (al-Mas'ūdī, 2012, p. 20/2). Al-Bakri (1999, p. 31) described Ābeskun as a small village on the Caspian shoreline in 1208 . In 1219 it was disturbed due to an increase of the CSL which Mostowfi (1999, p. 239) and Létolle (2000) assigned to the man-made avulsion of the Āmu-daryā towards the CS by the Mongols (sons of Genghis Khan). The suggestion of Mostowfi (1999), linking the Ābeskun flooding to the river avulsion, could also be possible as the largest observed amount of the Amu-Daryā discharge in the 20th century (around 98 cubic kilometres per year) to flow into the CS, raised the CSL by $2 \mathrm{~m}$. The Italian traveller Marin Sanudo (1320, in Gümilev, 1980) mentioned that the sealevel rise in the early fourteenth century was catastrophic and destroyed many important cities around the CS. The 1304 rapid sea-level rise accentuated the demise of the Khazars dominion on the northern coast of the CS (Gümilev, 1980). Berg (1949, in Gümilev, 1980) reported that the CSL rise in the fourteenth century could not have reached more than $-24 \mathrm{~m}$, while Gümilev (1980) believed that the sea level rose up to $-19 \mathrm{~m}$ based on articulated bivalve shells, dated to the fourteenth century, on a historical wall near the Terek River, Russia.

Jayhāni (1989, p. 146) noted that at the end of ninth century, in an area between Māzandarān and Gilān (near the 
Table 5. Summary of the dates of the Caspian sea level based on historical documents and uncalibrated radiocarbon ages (Karpychev, 1998, 2001).

\begin{tabular}{llr}
\hline Year & Information & CSL (m) \\
\hline $600-900$ & Silt in Turkmenbāshi Bay & -28 to -31 \\
$800-1300$ & Dating & $<33$ \\
1234 & Building of a caravanserai in Derbent & $<-31$ \\
& which was submerged later & \\
$1300-1304$ & Dating & -28.5 \\
$1305-1306$ & Settlement of Bayandovan was flooded & -28 \\
$1300-1400$ & Dating & rise to -24 \\
$1380-1395$ & Dating & -29.0 \\
$1430-1450$ & Dating & -26.0 \\
$1480-1490$ & Dating & -31.0 \\
$1550-1680$ & Dating & -22.0 \\
$1587-1606$ & A tower was added to a wall near the & -28.5 \\
& water line in Derbent & \\
$1710-1720$ & Dating & -26.0 \\
$1740-1750$ & Dating & -24.5 \\
$1740-1750$ & Many lines of historical evidence & -23 \\
1760 & Underwater fortification & $<23$ \\
$1770-1790$ & Dating & -25.0 \\
$1795-1810$ & Dating & -22.0 \\
$1850-1900$ & Dating & -25.0 \\
\hline
\end{tabular}

present city of Rāmsar, Fig. 3) the sea and the mountains were in contact and the only way to cross the area was through the mountains. This observation is supported by Ibn Hawqal (1988, p. 120) who noted that "Chālus is the entrance of Daylam (Gilān) and the city opens to the sea and only one guardsman is enough to close the way" (Fig. 8). Today, the foothills of the Alborz Mountains extend to the sea at $-23 \mathrm{~m}$ in Rāmsar, just at the border of Māzandarān and Gilān. According to the above-mentioned reports, it seems that the CSL in the tenth century rose up to $\leq-23 \mathrm{~m}$ and the sea level was more or less around the same level until the thirteenth century. This is corroborated by the position of Ābeskun that remained a port from the ninth to the thirteenth centuries. After this time, the sea level started to rise around 1208 and finally reached $-19 \mathrm{~m}$ in the fourteenth century (Gümilev, 1980).

About $250 \mathrm{~km}$ north of Ābeskun a populated region was known as the Dahestān District (Barthold, 1984). According to the approximate position of Ābeskun in Gomishān (Barthold, 1984; Rabino, 1917), the Dahestān District could be somewhere around the present Turkmenbāshi Bay (Fig. 1), where Barthold (1984) claimed that he found ancient ruins of the city in Qezel Ârvāt, tens of kilometres from the shoreline (the exact position is not yet known).

al-Maqdisī (1982, p. 525) mentioned that the Dahestān District comprised 24 villages and the capital of the district was Ākhor on the Caspian shoreline. Ibn Hawqal (1988, p. 130) remarked that the sea level started to fall in 977 when he met Ākhor as the sea became shallow and let the ship and boats use it as a shelter during stormy conditions.
Barthold (1984) reported that people in the tenth century constructed a $50 \mathrm{~km}$-long channel from the Atrak River to Dahestān to provide fresh water to its people.

The anonymous writer of the Hudud al-'Alam (written in 982; 1973, p. 46) highlighted that in 982 the CS did not have any bays but it had two islands; one of them was known as Siāh Kuh. The other island was on the western side of the CS in front of Bāb (Fig. 7) and was called the Jazirat al Bāb (Bāb Island). It is reported in Hudud al-'Alam (1973, p. 47) that a peninsula existed in front of Dahestān, named DahestānānSar (the Dahestān Cape) and it was a place for hunting. This report may support the approximate position of the Dahestān District around Turkmenbāshi Bay as the Cheleken peninsula (Fig. 1), at ca. $50 \mathrm{~m}$ in elevation, could be considered as the Dahestān Cape. The report of the Hudud al-'Alam (1973) is supported by Ibn Hawqal (1988, p. 129), who referred to Siāh Kuh Island as Siah Kubeh (Fig. 7). He also located the Bāb Island in front of the Kur River (Kura River, in modern Azerbaijan). Ibn Hawqal (1988, p. 129) wrote that the Bāb Island was a grazing land and locals brought their cattle to the island to fatten them. If this is true, then the water between the island and main land was possibly shallow. According to the position of the Bāb Island (Fig. 7), this island could be consistent with Chechen Island with $-23.8 \mathrm{~m}$ elevation (Varushchenko et al., 1987), which was reported by other historians such as Genuetzev (in Varushchenko et al., 1987).

Although Ibn Hawqal (1988) and the Hudud al-'Alam (1973) described only two unoccupied islands in the tenth century, al-'Umarī (2010) in 1349 remarked that several islands existed in front of the city of Rasht and people used them as a haven when they were attacked by pirates.

Mostowfi (1999, p. 142) mentioned that a bay existed on the south-eastern flank of the CS, near Ābeskun and called it the Nim-mardān Bay (the Half-men Bay). According to his remarks, the Gorgān River discharged close to Ābeskun into the bay. Attributing the name of Nim-mardān to the bay could be interpreted as a shallow-water bay in which fishermen could stand in order to fish (Nahchiri, 1999), the same way as fishermen do today in Gomishān. Nahchiri (1999) also believed that Nim-mardān Bay is the present Gorgān Bay. However, based on other historical evidence, the proposed position of Ābeskun by some geographers (Barthold, 1984; Rabino, 1980) and new geological findings from the Gorgān Bay (Kakroodi, 2012) mean that Nahchiri's suggestion seems unlikely. It is, therefore, more likely to link Nim-mardān Bay to the present Hassanqoli Bay (Fig. 3).

\subsubsection{Caspian sea level during the sixteenth to seventeenth centuries}

In 1628 Ashraf al-Belād (the Ashraf port) was constructed on the southern flank of the Gorgān Bay (present-day Behshahr; Fig. 3) (Parodi, 1997). The remains of an old port of the Safavid era (1501-1722) were found at an altitude 


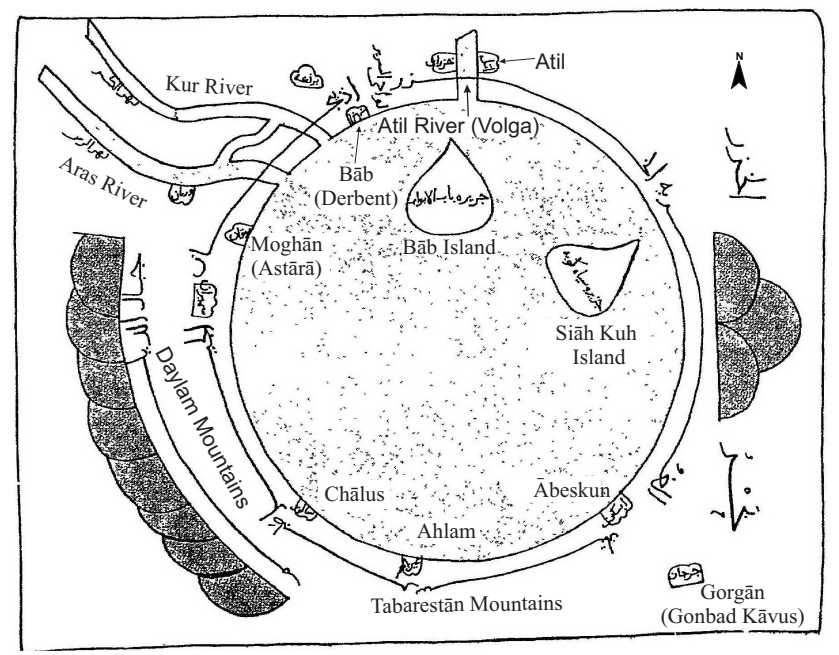

Fig. 7. The tenth century map of the Caspian Sea by Ibn Hawqal (1988). The map was rotated to show the north at the top and some of the names have been translated into English. Ābeskun, Gorgān, Ahlam and Chālus were described as the most important ports of the south Caspian Sea by the tenth century geographer.

of $-23.5 \mathrm{~m}$ in the plain of Behshahr, south of Shāhkileh (Asgari, 1971) (Fig. 3), which could be linked to this information. The seventeenth century sea-level rise was mentioned by Kotov, a Russian entrepreneur who described the inundation of a castle in Derbent in 1623 (Gümilev, 1980). This castle was built on the site of the Sasanian fortified town in 1587 , and the remains of the structure were found at $-28 \mathrm{~m}$ by Russian archaeologists (Gümilev, 1980).

According to the above-mentioned reports, it seems that sea level rose to $-23 \mathrm{~m}$ in the seventeenth century after a sea-level fall during the sixteenth century (see also Brückner, 1890; Table 3).

\subsubsection{Caspian sea level during the eighteenth to twentieth centuries}

Changes in the position of the Caspian's shoreline have been mentioned in more recent literature such as Farhād Mirzā (1987, p. 26) who stated that a royal tower, built in 1868 in Anzali (Fig. 2), was subsequently threatened by sea water in 1875. According to Rabino (1917), the building was demolished in 1913. The modern watchtower of the Anzali port has been built near the same position at about -25 m elevation on a concrete foundation (www.anzali.ir).

Due to its vast area, the Anzali Lagoon was described as a bay by Gmelin in 1771 (Rabino, 1917). This suggests a higher CSL in 1771 than today, previously reported by Brückner (1890) at -23 m elevation. Abbott (1858) indicated that Anzali water was influenced by sea waves during his stay in Gilān from 1847 to 1848. Eastwick (1864 in Rabino, 1917) explained that the coastal plain of Anzali was flat because during storm conditions the lagoon water surged onto the land without any obstacle, destroying boats in Anzali as well as the more inland site of Pirbāzār near Rasht (Fig. 3).

Rabino (1980) wrote that the Gorgān Bay was the safest place in the CS for ships, and followed that from 1860 to 1906 the area of the Gorgān Bay had been dramatically reduced. According to his report, the Galugāh farmlands on the southern coast of the Gorgān Bay (Fig. 8) were completely inundated in 1815. This information supports Moraviev's observation (in Rabino, 1980), reporting that Gomishān was an island in 1815 , while the city was $3 \mathrm{~km}$ from the shoreline when Rabino visited the city in 1906. A high-stand at and before 1805 with values of -22.7 and $-22.0 \mathrm{~m}$ were also reported by Brückner (1890) and Karpychev (2001), respectively (Fig. 6).

It seems that the CSL underwent fluctuations from 1771 to 1900 and that the area of the Anzali Lagoon and Gorgān Bay changed in accordance with these fluctuations, as their surface area reduced during low stands and increased during high-stands.

\subsubsection{Unexpected Caspian sea-level fluctuations}

Tusi (1966, p. 82), in 1160 noted that: "Earthquakes can cause disturbances along the shorelines, and the properties close to sea shake and are impacted by the water and waves. I have heard from people of Gilān that the Kabudān [Blue] Sea was agitated by high tides, the city of Ardébil was shaken; and the distance of Ardébil to the Kabudān Sea is 12 farsangs $(\sim 72 \mathrm{~km})$ ".

The "Kabudān Sea" (the Blue Lake) is the ancient name of the Lake Urumiyeh (Fig. 1), but it is located about $240 \mathrm{~km}$ to the west of Ardébil, while the CS is located $55 \mathrm{~km}$ to the east of Ardébil. The author seems to be confused with the correct names of the seas. It is probable that the people of Gilān were referring to the $958 M_{\mathrm{S}} \sim 7.7$ Ruyān (central Alborz) earthquake (Ambraseys and Melville, 1982; Berberian, 1994; Berberian and Yeats, 1999, 2001), which might have caused some changes in the CSL. It seems unlikely that the reference is made to the $957 \mathrm{M} \sim 5.5$ Derbent earthquake (Kondorskaya and Shebalin, 1977, 1982, p. 71), because of the much lower magnitude and farther distance of the latter to the south Caspian shore.

Based on the publication by Kazin (1974), who gave the year 915, and Nikitin (1974) citing the period 915-921, Kondorskaya and Shebalin $(1977,1982$, p. 71$)$ reported that during the $918 M_{\mathrm{s}} \sim 5.5$ earthquake in Derbent (Fig. 1), the Caspian shore with the fortress walls sank. This event definitely caused abnormal waves in the Derbent area of the western CS. On the authority of Nikitin (1963) who dates the event to 968, Kondorskaya and Shebalin $(1977,1982$, p. 71) reported an earthquake in 957 with $M_{\mathrm{S}} \sim 5.5$ in the west Caspian where the sea experienced horizontal displacement of the shoreline towards the sea by around $150 \mathrm{~m}$ from its normal position. 
The 20 April $1608 M_{\mathrm{S}} \sim 7.6$ Alamutrud (West Alborz) earthquake, about $55 \mathrm{~km}$ to the SW of the CS shore (Berberian and Walker, 2010), caused large waves in the CS, which crashed up the coast and resulted in great alarm among men and animals (Ambraseys and Melville, 1982).

Abnormal fluctuations were also observed at Baku, Lankarān and the southern Caspian shore, where sea level oscillated within the space of an hour by fifty to more than a hundred centimetres in 1868 and 1960 (Hedin, 1892; Musketov and Orlov, 1893; Ambraseys and Melville, 1982).

Large sea waves were also observed at Āstārā associated with the 4 December $1910 M_{\mathrm{S}} 5.4$ Moghān earthquake (Kondorskaya and Shebalin, 1977, 1982, p. 99). Large seawaves were noticed all along the southern Caspian coast from Miānkāleh in the east to Anzali in the west (Ambraseys and Melville, 1982) during the 11 July 1890, $M_{\mathrm{S}} \sim 7.2$ Tāsh earthquake in the east Alborz, about $60 \mathrm{~km}$ to the SE of the Caspian shore.

Sea waves flooded the coast of the Cheleken Island during the 8 July $1895 M_{\mathrm{S}} 7.5$ Krasnovodsk (Qezel Suyu, Turkmenbāshi) earthquake on the eastern Caspian shore (Kondorskaya and Shebalin, 1977; Ambraseys, 1997). The water in the harbour quickly swelled and reached the railroad tracks. A ship $30 \mathrm{~km}$ from Krasnovodsk reported that the sea swelled with the shock and ejected a column of water and smoke (possibly linked to the eruption of a submarine mudvolcano).

During the 1 September $1962 M_{\mathrm{W}} 7.0$ Bu'in earthquake, which took place $142 \mathrm{~km}$ to the SW of the Caspian shore, some irregularities in the behaviour of the water level of the CS were noticed at the Anzali, Naushahr and Bābolsar ports, where waves followed the earthquake. The tide gauge records at the Anzali port showed abnormal variations in sea level before and after the earthquake; waves with amplitudes of nearly two feet and periods between 15 and 50 min were recorded. At the Naushahr port, a series of swells had been reported but made no noticeable damage. In addition, the morning after the earthquake, the CS was muddy for more than a nautical mile (Ambraseys, 1962, 1963).

The 20 June $1990 M_{\mathrm{w}} 7.3$ Rudbār earthquake (Berberian et al., 1992; Berberian and Walker, 2010), which was much larger than the $1962 M_{\mathrm{w}} 7.0 \mathrm{Bu}$ 'in earthquake, and its epicentre was closer to the CS (about $68 \mathrm{~km}$ to the SW of the Caspian shore vs. $142 \mathrm{~km}$ ), should have caused unusual fluctuations in the CS, much greater than the 1962 event. Unfortunately, our efforts in obtaining the hourly/daily records from the south CS failed because the gauge station was destroyed during the earthquake.

\subsubsection{Other historical findings}

Ibn Hawqal (1988, p. 141) in the tenth century described the Aral Sea (Fig. 1) as a salt lake that had not been freshened even by the Āmu-daryā water: "Although considerable water from the Jayhun River (Āmu-daryā) discharges into the lake, the area of the lake has not been increased and the water is not freshened and people believe that the lake is connected to the CS via an underground channel". Although this is corroborated by the Hudud al-'Alam (1973, p. 55), Mostowfi (1999, p. 239) mentioned that the Jayhun River (Āmu-daryā) was diverted from the Aral Sea towards the CS by the sons of Genghis Khan when they surged towards Iran in 1219 (Létolle, 2000).

Mar'ashi (1982, p. 134) quoted that during the invasion of Māzandarān by Uzbeks in 1392, the army invaded Āmol (Fig. 8), then arrested people and after that transferred them to Khärazm by ship from the CS and the Jayhun River. This story indicates that Āmu-daryā was discharging into the CS at that time via the Uzboy waterway. According to Barthold (1984), this waterway was open until the late sixteenth century.

In addition to the above-mentioned river avulsion, some reports of other Caspian rivers provide useful information on the south Caspian river courses.

The Sefidrud was reported as the largest river on the south Caspian coast in the Hudud al-'Alam (1973, p. 149). According to this report (written in 982), the people of Gilān could be categorized into two groups, the first group settled between the river and the Sea i.e. Rasht, while the other group was situated between the river and the mountains i.e. Lahijān (Fig. 1). Regarding the East-West direction of the Alborz Mountains (Fig. 1), this categorization is true when the river direction is parallel to the mountains and flows eastward on the plain. Rabino (1917) stated that in 1740 a large tributary separated from the Sefidrud, $6 \mathrm{~km}$ south of the river mouth, and discharged into the Anzali Lagoon, and that this tributary was large enough to enable ships to carry passengers from Anzali to Pirbāzār near Rasht. This tributary could be navigated in 1875 because Farhād Mirzā (1987) used it in his journey to Europe. Barthold (1984) mentioned that the tributary was called Shāhrud and discharged into the Anzali Lagoon at the beginning of the twentieth century. At present, this tributary is abandoned.

The Gorgann River, on the south-eastern flank of the CS (Fig. 8), according to Rabino (1980), discharged into the Gorgān Bay before 1854 near Bāsh Youzki (the present Bandar Turkman, Fig. 1). Then the river avulsed northward and split into two tributaries. In 1886 the southern branch of the river was completely abandoned and the river discharged into the CS at Khājeh Nafas where it still meets the sea to this day. According to this account, the present delta of the Gorgān River has been in formation since just 1854 .

\section{Discussion}

\subsection{Caspian sea-level during the last millennium}

The CSL during the tenth century is the most controversial time period for the last millennium as it has been reported 
Table 6. Historical earthquakes in the Caspian Sea region and the observed consequences on the sea level (Modified after Dotsenko et al., 2002).

\begin{tabular}{|c|c|c|}
\hline Year (AD) & Location & Evidence \\
\hline 918 & Derbent & Part of the coast with fortifications was submerged in the sea. \\
\hline $957-972$ & Derbent & The fall of sea level caused horizontal displacement of the shoreline by around $150 \mathrm{~m}$ from its original position. \\
\hline 958 & Ruyān & The Caspian Sea in Gilān was agitated by high tides. \\
\hline 1668 & Terka & The sea submerged part of the beach. The rise of water level was observed in the delta of the Terek River. \\
\hline 1868 & Bāku & Short-term rise and fall of sea level with an amplitude of about $0.45 \mathrm{~m}$ were observed. \\
\hline 1876 & Oblivnoy (island) & $\begin{array}{l}\text { Unusual sea-level oscillations occurred after strong underwater explosion in conditions of dead calm. Event was } \\
\text { observed from the ship. }\end{array}$ \\
\hline 1890 & Tāsh & Large sea waves were noticed along the Caspian coast of Iran. \\
\hline 1895 & Cheleken Island & $\begin{array}{l}\text { Flooding of north and west areas of Uzun-Ada as a result of a rise in water level in the bay. Large waves caused } \\
\text { flooding of buildings and the dock. A few wooden houses were washed out to sea. Pipeline was destroyed. }\end{array}$ \\
\hline 1902 & Bāku & $\begin{array}{l}\text { Unusual waves resulted in dangerous motion of ships in the port. The event was observed after a destructive } \\
\text { earthquake near Shimaha. }\end{array}$ \\
\hline 1910 & Moghān & Large sea waves were observed in Āstārā. \\
\hline 1933 & Kuuli-Mayak & $\begin{array}{l}\text { Sudden rise of sea level up to } 1.35 \mathrm{~m} \text { for } 10 \mathrm{~min} \text {. } \\
\text { Fishing boats and equipment were washed out to sea. }\end{array}$ \\
\hline 1939 & Livanov Shoal & The passing of a solitary large wave was observed from two ships that were 15 miles apart. \\
\hline 1960 & Bāku & Sea-level oscillations up to $1 \mathrm{~m}$ were observed for $2-3 \mathrm{~h}$. \\
\hline 1962 & Bu'in & Irregularities were noticed at Anzali, Naushahr and Babolsar ports. \\
\hline 1986 & Livanov Shoal & $\begin{array}{l}\text { Unusual high-frequency sea level oscillations of } 2-3 \mathrm{~cm} \text { amplitude were observed over the earthquake for } 1- \\
1.5 \mathrm{~min} \text {. The event was fixed from the seiner and } 45 \text { fishing ships. }\end{array}$ \\
\hline
\end{tabular}

at less than $-35 \mathrm{~m}$ by Varushchenko et al. (1987), $-33 \mathrm{~m}$ by Gümilev (1980) and Karpychev (1998, 2001) up to more than $-17 \mathrm{~m}$ by Brückner (1890) during the early tenth century (Fig. 6). Because the shoreline accommodating the fort walls in Derbent sank due to the 918 earthquake (Kazin, 1974; Nikitin, 1974) (discussed earlier), the sea-level position mentioned by Brückner (1890) for 915 to 921 (Table 3) could partially be related to coastal subsidence rather than sea-level rise. As Brückner (1890) compared paintings of that period with those in 1638 and estimated the CSL difference between both periods from how many projections in the wall were reached by water ( 6 in 915-921 and 3 in 1638), it is also possible that the wall might have been altered. According to the existence of Ābeskun as a port from the beginning of the ninth century (al-Istakhri, 1961; Ibn Hawqal, 1988) to the beginning of the fourteenth century (Mostowfi, 1999), and the historical observations in Chālus and Rāmsar (Hudud al'Alam, 1973; Ibn Hawqal, 1988), it is probable that sea level during this period did not change as dramatically as mentioned. This suggestion is supported by the reports on the CSL during the next catastrophic sea-level rise in the fourteenth century with a maximum level at $-19 \mathrm{~m}$ (Gümilev, 1980) that drowned Ābeskun and was much greater than the high-stand of the first half of the tenth century. As the approx- imate position of the Ābeskun possibly lies at about $-24 \mathrm{~m}$ elevation, the sea-level position in the early tenth century was at least $-24 \mathrm{~m}$ as the CSL must have been lower than the height of the town, which could be supported by the geological findings of Lahijani et al. (2009), who described a sealevel rise during the first centuries of the last millennium to around $-24 \mathrm{~m}$ in central Gilān.

According to Ibn Hawqal's (1988) observations in 977 in the Dahestān District, it seems that the sea level started to fall during the second half of the tenth century, which has been reported elsewhere in the scientific literature (Leroy et al., 2011; Kakroodi et al., 2012) as the Medieval Climate Anomaly (MCA) low-stand. A horizontal displacement of the shoreline in 957 in Derbent (Dotsenko et al., 2002) could also be related to this sea-level fall rather than the seismic event. Although the MCA in the North Atlantic region extended to the middle of the thirteenth century (Ruddiman, 2008), the observations of al-Bakri (1999) and Jovayni (1911) in the early thirteenth century suggest that the regression did not stretch beyond 1208. At this time sea level started to rise and reached the highest level at the beginning of the fourteenth century (Banāketi, 1969; Mostowfi, 1999). This observation could be correlated with the dating results of Kakroodi et al. (2012) in Gomishān and Naderi 
Table 7. The Caspian sea level (CSL) during the last millennium based on comparison between historical observations and geological events.

\begin{tabular}{|c|c|c|c|c|c|c|}
\hline No & Age (AD) & CSL (m) & Historical Observation & Reference & Geological event & Reference \\
\hline 1 & 907 & -23 & $\begin{array}{l}\text { Sea level position in } \\
\text { Ahlam, Chālus and } \\
\text { Rāmsar }\end{array}$ & $\begin{array}{l}\text { Hudud al-'Alam (1973), } \\
\text { Ibn Hawqal (1988), } \\
\text { Jayhāni (1989) }\end{array}$ & $\begin{array}{l}\text { Progradation of the old } \\
\text { Kura Delta }\end{array}$ & $\begin{array}{l}\text { Hoogendoorn et } \\
\text { al. (2005) }\end{array}$ \\
\hline 2 & 977 & -24 & Sea level fall in Dahestan & $\begin{array}{l}\text { Hudud al-'Alam (1973), } \\
\text { Ibn Hawqal (1988) }\end{array}$ & Sea-level fall & $\begin{array}{l}\text { Hoogendoorn et } \\
\text { al. (2005) }\end{array}$ \\
\hline 3 & 982 & $\gg-23.8$ & Bāb Island is in the map & $\begin{array}{l}\text { Hudud al-'Alam (1973), } \\
\text { Ibn Hawqal (1988), }\end{array}$ & - & - \\
\hline 4 & 1208 & -24 & $\begin{array}{l}\text { Ābeskun was on the } \\
\text { shoreline }\end{array}$ & Al-Bakri (1999) & - & - \\
\hline 5 & 1260 & $>-24$ & Ābeskun was flooded & Jovayni (1911) & High-stand & Naderi Beni et al. (2013) \\
\hline 6 & 1304 & -19 & Rapid sea-level rise & $\begin{array}{l}\text { Banāketi (1969), } \\
\text { Mostowfi (1999), } \\
\text { Marin Sanudo (1320 } \\
\text { in Gümilev, 1980), } \\
\text { Al-'Umarī (2010) }\end{array}$ & High-stand & $\begin{array}{l}\text { Kakroodi et al. (2012), } \\
\text { Naderi Beni et al. (2013), } \\
\text { Rekavandi et al. (2007) }\end{array}$ \\
\hline 7 & 1587 & -28 & $\begin{array}{l}\text { Construction of Safavid } \\
\text { castle in Derbent }\end{array}$ & Gümilev (1980) & - & - \\
\hline 8 & 1628 & -23 & $\begin{array}{l}\text { Establishment of ports } \\
\text { and structures along the } \\
\text { Caspian Sea coast }\end{array}$ & $\begin{array}{l}\text { Parodi (1987), } \\
\text { Gümilev (1980) }\end{array}$ & $\begin{array}{l}\text { Sea-level rise and barrier } \\
\text { formation }\end{array}$ & $\begin{array}{l}\text { Kroonenberg et } \\
\text { al. (2007) }\end{array}$ \\
\hline 9 & 1771 & -23 & Sea-level rise & $\begin{array}{l}\text { Abbott (1858), } \\
\text { Brückner (1890), } \\
\text { Rabino (1980), }\end{array}$ & Widespread evidence & $\begin{array}{l}\text { Leroy et al. (2011), } \\
\text { Naderi Beni et al. (2013) }\end{array}$ \\
\hline 10 & 1815 & -23.5 & $\begin{array}{l}\text { Sea-level position in } \\
\text { Galugāh and Gomishān }\end{array}$ & Rabino (1980) & $\begin{array}{l}\text { Anzali Spit broken into } \\
\text { barriers }\end{array}$ & Leroy et al. (2011) \\
\hline 11 & 1875 & -25 & $\begin{array}{l}\text { Sea-level rise at Anzali } \\
\text { royal tower }\end{array}$ & Farhād Mirzā (1987) & Karā Bogāz Gol & Leroy et al. (2006) \\
\hline
\end{tabular}

Beni et al. (2013) in Anzali. The rapid catastrophic sea-level rise in 1304 (Brückner, 1890; Gümilev, 1980; Karpychev, 2001) inundated Ābeskun completely and engendered spitlagoon development along different stretches of the Caspian coastal areas (Kroonenberg et al., 2007; Storms and Kroonenberg, 2007; Naderi Beni et al., 2013). The formation of Nim-mardān Bay (Mostowfi, 1999) could possibly be linked to this rapid sea-level rise that is reflected in the study of Kakroodi et al. (2012) as a shell-bearing layer. The successive transgressions of the thirteenth and fourteenth centuries are also recorded in the Anzali Spit as two different horizons of shell-bearing sands (Naderi Beni et al., 2013), as well as in Dagestan (Kroonenberg et al., 2007), the Gorgān Wall (Rekavandi et al., 2007) and Gomishān (Kakroodi et al., 2012).

According to the historical documents presented in this study, the geological findings in the south CS (Table 7), and other evidence reported by Brückner (1890), Varushchenko et al. (1987) and Karpychev (1998, 2001), in addition to other findings by Komarova (1980) and Gümilev (1980) from other parts of the CS, the sea-level curve could be reconstructed as illustrated in Fig. 9.

\subsection{Dating Caspian sea level changes during the last millennium}

The RE in a closed environment such as the CS is more variable and coupled with more uncertainties in time and space than in the open ocean (Walker, 2005). It means that the present-day age of seawater may not necessarily be applicable for correction of fossil material from a particular locality (Walker, 2005).

However if a RE is applied to the dating results of this study, then the ages could be linked to the younger highstands of the fifteenth to the nineteenth centuries (Fig. 9, rectangle I). According to the elevation of the dated horizons of cores $\mathrm{A}$ and $\mathrm{B}$ at $-26.75 \mathrm{~m}$ and $-25.8 \mathrm{~m}$, respectively (Table 2), and the reconstructed sea-level curve (Fig. 9), the sealevel rise in the seventeenth century is more appropriate for the dated horizons. During the tenth to seventeenth centuries the sea level was always higher than $-26 \mathrm{~m}$ and hence the terrestrial facies below the dated horizons in cores A and B (Fig. 4) could only be formed during the sixteenth century low-stand. 


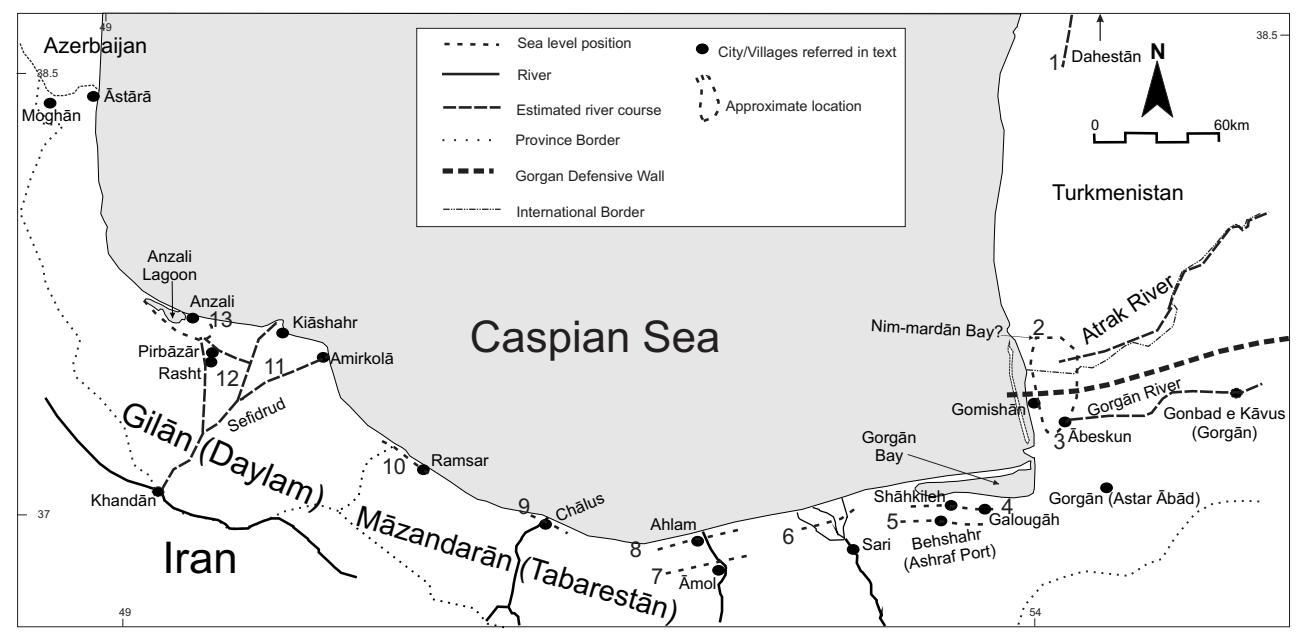

Fig. 8. The Iranian Caspian coast and reported historical observations. The ancient names are denoted in parentheses: (1) the possible position of sea level in Dahestān in the second half of the tenth century (al-Istakhri, 1961, 1973; Barthold, 1984; Ibn Hawqal, 1988). (2) The probable position of Nim-mardān Bay (Mostowfi, 1999; Kakroodi et al., 2012). (3) The probable position of Ābeskun along the Caspian shoreline (Jovayni, 1911; al-Istakhri, 1961; Ibn Hawqal, 1988; Mostowfi, 1999; al-Mas'ūd̄̄, 2012). (4) The sea-level position in 1906 in Galougāh (Rabino, 1980). (5) The position of Ashraf port in 1628 (Parodi, 1997). (6) Uzbeks shipped the captives of Māzandarān from Sāri (Mostowfi, 1999). (7) Sea-level position in Ahlam in the ninth century (al-Ya'qūbī, 1968). (8) Sea-level position in Ahlam reported by Ibn Hawqal (1988), Mostowfi (1999) and Mar'ashi (1982). (9) Sea-level position in Chālus reported by Ibn Hawqal (1988) and Jayhāni (1989) in the tenth century. (10) Sea-level position in an area between Daylam and Māzandarān in the tenth century (Ibn Hawqal, 1988; Jayhāni, 1989). (11) The Sefidrud or its tributary course in the tenth century (Hudud al-'Alam, 1973). (12) The main course of Sefidrud and its tributary in the eighteenth and nineteenth centuries (Rabino, 1917; Barthold, 1984; Farhād Mirzā, 1987). (13) The Anzali Spit broke into barrier islands in the fifteenth century (Mar'ashi, 1982).

Owing to frequent CSL changes during the Holocene (Kroonenberg et al., 2000), and owing to the poorly known $\mathrm{RE}$ of the CS, many researchers prefer to conduct their interpretations based on uncalibrated ages (e.g. Rychagov, 1997; Pierret et al., 2013), or on calibrated age data (IntCal09 curve) but with different RE ranging from 290 to 438 yr. Using IntCal09 with RE subtracted produces somewhat tighter calibrated ages ranges than using Marine 09 with $\Delta \mathrm{R}$ when the overall calibrated age ranges are considered (Fig. 9).

\subsection{Hydroseismicity and Caspian sea-level changes}

Following Shilo and Krivoshey (1989), Rodkin (1992a, b) reported some correlation between the seismic and hydrodynamic regimes in the CS area and the observed delay times between the CS water imbalances (oscillations in water level due to river inflow, precipitation over the Sea, evaporation and outflow from the sea) and regional seismicity. The hydroseismic research avenue was later followed by Ulomov (2003), who found some correlation between seismicity and hydrological variations in the central and south CS by utilizing regional $M>6.0$ magnitude earthquakes. Since reliable instrumental measurements on CSL fluctuations before the mid-nineteenth century are not available, the first largemagnitude earthquake selected by Ulomov (2003) was the $1895 M_{\mathrm{S}} 7.4$ Krasnovodsk (Cheleken) earthquake along the eastern Caspian shore (though he assigned a $M$ 8.0). Most of the earthquakes were apparently preceded by a short rise in the CSL followed by noticeable sea-level drops.

Nonetheless, some of the large-magnitude events selected by Ulomov (2003) such as the 1930 Salmās, 1948 Ashkābād, 1968 Dasht-e Bayāz, 1978 Tabas-e Golshan, 1979 Koli, and 1990 Rudbār earthquakes, macro-seismic epicentres are far from the Caspian shoreline (360, 400, 520, 450, 430, 570, and $68 \mathrm{~km}$, respectively). Hence, some of his data points may not be closely linked to the hydroseismicity of the CS. Despite deleting most of his $M>7.0$ earthquakes, if his correlation is still valid, then one can state that the factors controlling the fluctuations of the CSL may also partially contribute to the seismicity of the basin and lead to destruction of coastal settlements as well as changing shorelines. These kinds of destruction, although short in time, should be considered in any historical, geological and archaeological reconstructions of CSL changes. In spite of the rich historical evidence related to seiche generation in the CS and its theoretical supports, no individual studies have been conducted to show the sedimentological impacts of seismic sealevel changes. However, in some cases, such as Lahijani et al. (2009), the evidence of sea level rise was indicated during the MCA that is characterized firmly by a low-stand by many researchers. Although this apparent contradiction could be related to dating techniques, it could also be related to shortterm CSL rise due to seismic activity. 


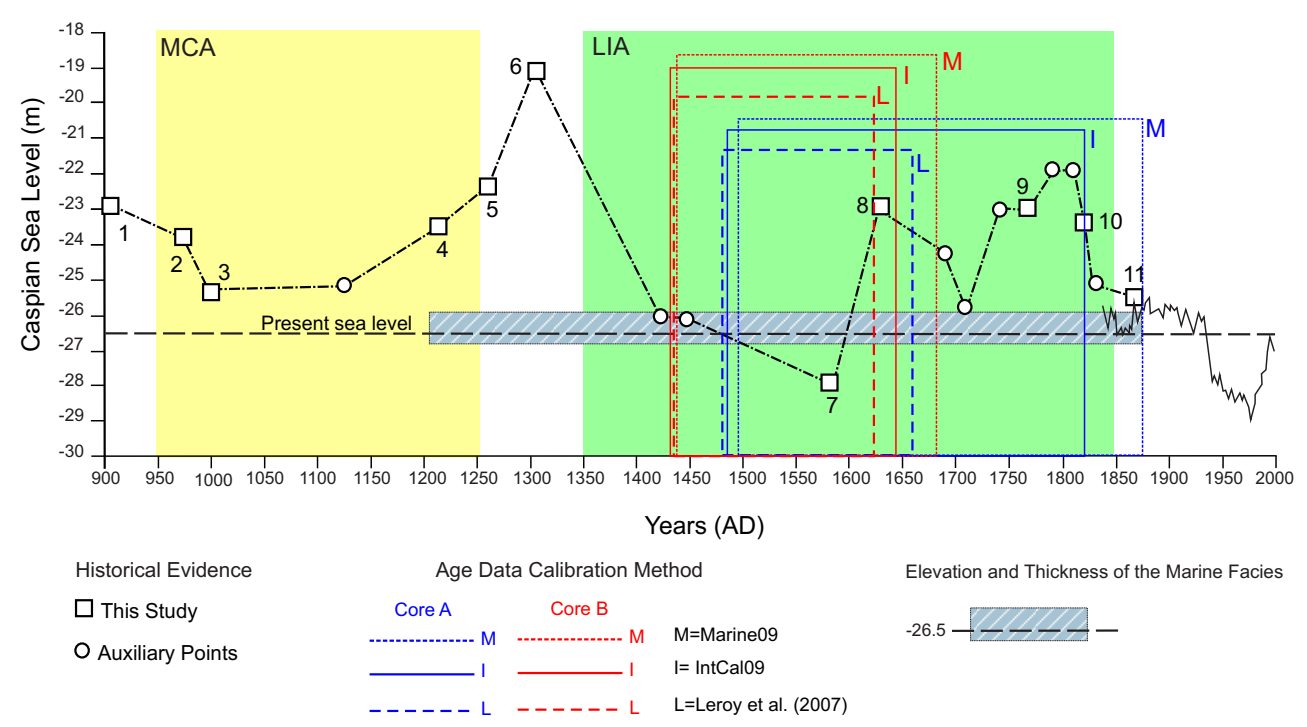

Fig. 9. Caspian sea-level curve for the last millennium based on historical evidence from this study (squares) and other researchers (Brückner, 1890; Varushchenko et al., 1987; Karpychev, 1998, 2001) denoted as circles. Numbers for the squares show the correspondent number of eleven historical reports in Table 7. The blue and red rectangles correspond to samples A and B, respectively (Table 2). Quadrangles with letters M, I and L are the ages of dated horizons in this study based on different calibration methods. M: Calibrated ages based on Marine09 curve with $\Delta \mathrm{R}=26 \pm 69$ (Kuzmin et al., 2007; Olsson, 1980). I: Calibrated ages based on IntCal09 curve and RE $=407 \pm 27$ (Kuzmin et al., 2007; Olsson, 1980). L: Calibrated ages based on IntCal09 curve and RE = 383 (Leroy et al., 2007). The widths of blue and red rectangles correspond to age ranges (Table 2) and the heights were chosen differently to clearly distinguish the rectangles. The coloured boxes show the Medieval Climate Anomaly (MCA) and the Little Ice Age (LIA). The horizontal dashed box shows the thickness of the oldest marine facies in this study (Fig. 4) for the same altitude and time range. The present Caspian sea level is shown as a dashed horizontal line.

\subsection{Validation of the last millennium sea-level curve}

Comparison of the CSL changes with the climate history of the last millennium shows that during the MCA (ca. 977 to 1208) the CSL experienced a low-stand; while during the LIA some significant sea-level fluctuations occurred (Fig. 9). The CSL rose up to $-19 \mathrm{~m}$ at the beginning of the fourteenth century (i.e. nearly $7 \mathrm{~m}$ higher than at present) and then dropped to $-28 \mathrm{~m}$ in the sixteenth century. Generally the CSL was high during the late LIA from the seventeenth to the nineteenth centuries, although with some fluctuations (Fig. 9).

The CSL changes during the last millennium manifest similarities with changes in Alpine lake levels (Magny et al., 2011) and the level of the Aral Sea (Boomer et al., 2009) (Fig. 10). Furthermore, there seems to be synchronicity between lake-level changes and solar activity during the last millennium (Bard et al., 2000) (Fig. 10). Decreases in solar irradiance are generally coincident with increasing CSL, Alpine lake levels (Magny et al., 2011) and the Aral Sea (Boomer et al., 2009), which could be related to increases in precipitation, decreasing temperatures and consequently a reduction in evaporation over the sea and its catchment basin (Arpe and Leroy, 2007; Leroy et al., 2011).

\subsection{Other findings}

Leroy et al. (2011) reconstructed environmental changes in the Anzali Lagoon and Spit during the LIA high-stand and concluded that barrier islands with inlets could be found during this period in place of the Anzali Spit. This suggestion is in good agreement with the observations of al- 'Umarī (2010) in the fifteenth century that described the presence of islands in front of Rasht. Generally, during the CS high-stands, spits could be split into barriers and inlets as Kakroodi (2012) have described for the Miyānkāleh Spit, in the southeast CS.

Kazanc1 et al. (2004) suggested that the Sefidrud flowed in an area between Amirkolā and the Anzali lagoons during its lifetime (Fig. 1). For the last millennium, this suggestion could be supported by the observations of Hudud al'Alam (1973), Farhād Mirzā (1987), Barthold (1984) and Rabino (1917) who mention different directions for the Sefidrud and its tributaries.

The Sefidrud avulsion was investigated by Leroy et al. (2011) and Naderi Beni et al. (2013). They showed that an avulsion occurred around the beginning of the seventeenth century and the river and/or one of its major tributaries avulsed from W-E to S-N direction. The W-E course of the river was observed by an anonymous writer of Hudud al-'Alam (1973).

River avulsion is one of the consequences of rapid sealevel change in the CS (Naderi Beni et al., 2013). During 


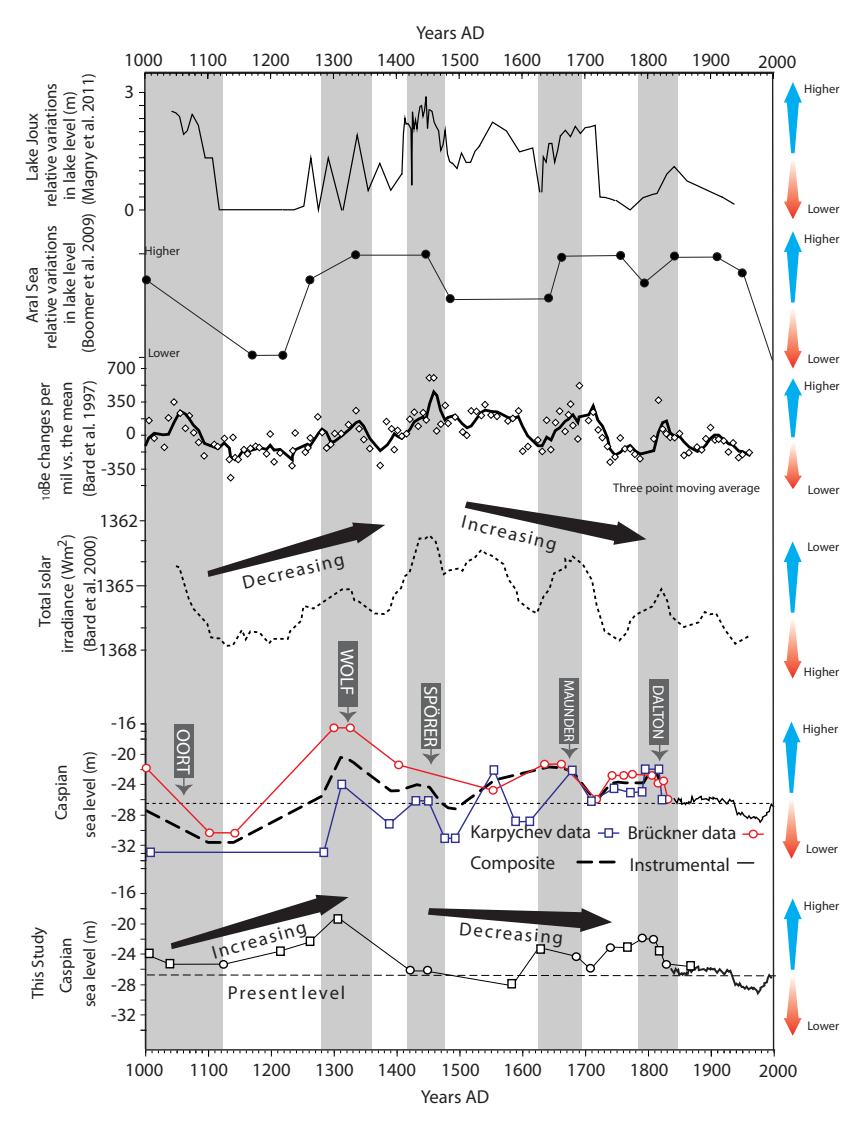

Fig. 10. Caspian sea-level reconstruction for the last millennium based on historical and geological evidence (Table 7). These data are compared with the curves of Brückner (1890) and Karpychev $(1998,2001)$ as well as the Aral Sea level fluctuations (Boomer et al., 2009) in Middle Asia and Lake Joux (Magny et al., 2011) in Europe. The lake-level fluctuations are compared with total solar irradiance (Bard et al., 2000) and ${ }^{10} \mathrm{Be}$ changes (Bard et al., 1997). The increasing and decreasing trends are highlighted on the right side of the graphs. The Aral Sea level fluctuations have not been precisely quantified and are depicted on a relative scale.

the late LIA, some rivers such as the Kura River (Hoogendoorn et al., 2005), the Gorgān River (Barthold, 1984) and the Sefidrud (Leroy et al., 2011; Naderi Beni et al., 2013) experienced changes in their main courses and/or tributaries that could be more or less correlated with major CSL oscillations. The thirteenth century Āmu-daryā avulsion (Mar'ashi, 1982; Mostowfi, 1999) from the Aral Sea to the CS could also be linked to changes in the level of the Aral Sea. According to Boomer et al. (2009), the Aral Sea experienced a severe regression in 1220 , which could be correlated with the thirteenth century avulsion of the Āmu-daryā. Boomer et al. (2009) also found a gypsum horizon in their Aral Sea cores with a date of 1200 and much higher water salinity in 1220. Moreover, Sorrel et al. (2006) reported that the salinity of the Aral Sea changed from more saline to less saline conditions around 1380. These findings could be correlated with the Āmu-daryā avulsion and the consequent decrease of fresh water input into the Aral Sea. This scenario fits well with Mostowfi's report (1999) that evoked damage to Jayhun Dam by Mongols that directed the water towards Ābeskun.

Palynological studies showed that from 2200 to $1700 \mathrm{yr}$ BP (calibrated age using Marine09), the salinity of the CS was lowered due to increasing freshwater inputs by the Volga River and the Āmu-daryā, which discharged into the sea at that time (Leroy et al., 2007). The suggestion of the Āmudaryā avulsion in 2200 to 1700 cal. yr BP (Leroy et al., 2007) and the historical records of the avulsion in the thirteenth century (Mostowfi, 1999) underscore the possibility and frequency of river avulsions between the two basins (see also Létolle, 2000).

\section{Conclusions}

This study looked to build a bridge between history, archaeology and geology to show the importance of a multidisciplinary approach in reconstructing sea-level changes in the CS during the last millennium. The historical evidence provides us with a better understanding of the impacts of CSL changes on the environment as well as human societies.

Owing to the descriptive nature of many historical sources, some uncertainties in quantifying sea-level variations still exist. These uncertainties may be related to observational errors, different standards in describing the events used by different historians and geographers and local irregularities such as seismic events and river avulsions. Considering the negligible rate of uplift/subsidence on the south CS coast during the last millennium, and due to the seismicity of the CS region, earthquakes could cause considerable vertical displacement of the shoreline in places such as Derbent. These local vertical movements should be taken into account when attempting to reconstruct CSL changes based on historical and archaeological evidence.

One of the ways to decrease these uncertainties is the correlation of the descriptive data with geological findings as well as the comparison of individual observations with other contemporaneous reports. The multidisciplinary approach leads to a better understanding of past environments and, moreover, to corroborate the accuracy of geological findings.

Some contradictions, however, occur between historical evidence and proxy-based interpretations when determining the relative sea-level position (e.g. historical sea level lowstand from 950 to 1250 , a period in which a high-stand was dated by Lahijani et al. (2009)). It seems that this problem partially comes from uncertainties in dating methods as well as our geological interpretations. Precisely constraining the RE of the CS is a high priority for future studies. Nonetheless, our study on the southeast CS shows that using the IntCal09 curve with subtracted RE for calibration of ${ }^{14} \mathrm{C}$ ages yields more reliable results for this particular region. 
As the CS and its watershed area spans the sub-tropics in the southwest to desertic climate in the east-northeast, and the humid mid-latitudes in the northwest of the watershed, this could provide a good opportunity for geoscientists to investigate climate change in the northern hemisphere. Comparison of the CSL reconstruction for the last millennium with solar irradiance and with the fluctuation of lakes in Middle Asia and Europe shows relatively good agreement between the different curves. Based on the antiphase relationship between the CSL changes and the solar irradiance during the last millennium, it could be concluded that the main historical CSL fluctuations have essentially been modulated by solar activity. However, in some periods no good agreement occurs between the curves, which could be linked to the absence of data from the CSL for certain periods as well as regional irregularities, such as earthquakes and river avulsions.

Despite these problems, this study is able to construct a curve of the CSL changes during the last millennium, which fits to a multitude of observational evidence and can be used for validating simulations with climate models. In the early part of the millennium the absolute values have a wider range of uncertainty but most data agree for the phases of CSL rise and fall.

Acknowledgements. This study has been conducted within the framework of a project entitled: "A comparative study of Holocene climate changes in coastal areas of the south-eastern and southwestern Caspian Sea based on geological evidence" that is funded by the Iranian National Institute for Oceanography (INIO). This study has also been supported by the Iranian Centre for International Scientific Studies and Collaboration (CISSC), Ministry of Science, Research and Technology of Iran, and its French partner Campus France in the framework of the Franco-Iranian Gundishapour Program. The publication is a contribution to the INQUA QuickLakeH project (No. 1227) and to the European project Marie Curie, CLIMSEAS-PIRSES-GA-2009-247512. We thank R. Jokar, M. Pourkerman, N. Ghasemi, and M. Hosseindoost for their support with field and laboratory work.

Edited by: M. Siddall

\section{References}

Abbott, K. E.: Notes on Ghilan, Proceedings of the Royal Geographical Society of London, 390-395, 1858.

al-Bakri, A.: Kitāb al-Masālik w-al-Mamālik, 604 AH/1208 AD, edited by: Ghareh Chānlou, H., Motarjem Publication, Tehran, Iran, 1999.

al-Istakhri: Masalik al Mamalik, 339 AH/951 AD, edited by: Afshar, I., Bongah e Tarjomeh va Nashr-e Ketab, Tehran, 1961.
al-Maqdisī, M. B. A.: A'san al-taqāsim fī ma'rifat al-aqālīm, 374 AH /985 AD, Mo'alefān va Motarjemān Publication, Tehran, Iran, 1982.

al-Mas'ūdī, A. I. A.-H.: Murūj al-dhahab wa-ma'ādin al-jawhar, 335 AH/947 AD, edited by: Payandeh, A., Elmi va Farhangi Publication, Tehran, Iran, 2012.

al-'Umarī, A. I. Y.: Masālik al-ab'ār fī mamālik al-am'ār, 749 AH/ 1349 AD, Dār al-Kutub al-'Ilmīyah, Bayrūt, Lebanon, 2010.

al-Ya'qūbī, A. B. W.: Kitāb al-buldān, 259 AH/873 AD, edited by: Ayati, M. E., Tehran Publication Co., Tehran, Iran, 1968.

Ambraseys, N. N.: The Buyin-Zahra earthquake of September 1962; a field report, Bull. Seism. Soc. Am., 53, 705-740, 1963.

Ambraseys, N. N.: The Krasnovodsk (Turkmenistan) earthquake of 8 July 1895, J. Earthq. Eng., 1, 293-317, 1997.

Ambraseys, N. N. and Melville, C. P.: A history of the Persian earthquakes, Cambridge University Press, Cambridge, 1982.

Arpe, K. and Leroy, S. A. G.: The Caspian sea level forced by the atmospheric circulation, as observed and modelled, Quaternary Int., 173-174, 144-152, 2007.

Arpe, K., Bengtsson, L., Golitsyn, G. S., Mokhov, I. I., Semenov, V. A., and Sporyshev, P. V.: Connection between Caspian Sea level variability and ENSO, Geophys. Res. Lett., 27, 2693-2696, 2000.

Arpe, K., Leroy, S. A. G., Lahijani, H., and Khan, V.: Impact of the European Russia drought in 2010 on the Caspian Sea level, Hydrol. Earth Syst. Sci., 16, 19-27, doi:10.5194/hess-16-19-2012, 2012.

Asgari, A.: Behshahr: Ashraf al-Belād, Tehran Publication, Tehran, Iran, 1971.

Banāketi, D. B. M.: Tārikh e Banāketi, 716 AH/1317 AD, Ja'far-e Shoār Publication, Tehran, Iran, 1969.

Bard, E., Raisbeck, G. M., Yiou, F., and Jouzel, J.: Solar modulation of cosmogenic nuclide production over the last millennium: comparison between 14C and Be10 records, Earth Planet. Sci. Lett., 150, 453-462, 1997.

Bard, E., Raisbeck, G., Yiou, F., and Jouzel, J.: Solar irradiance during the last 1200 years based on cosmogenic nuclides, Tellus, 52B, 985-992, 2000.

Barthold, V. V.: An historical geography of Iran, Princeton University Press, Princeton, 1984.

Berberian, M.: The southern Caspian: a compressional depression floored by a trapped, modified oceanic crust, Can. J. Earth Sci., 20, 163-183, 1983.

Berberian, M.: Natural hazards and the first earthquake catalogue of Iran, International Institute of Earthquake Engineering and Seismology, Tehran, 669, 1994.

Berberian, M. and King, G.: Towards a paleogeography and tectonic evolution of Iran, Can. J. Earth Sci., 18, 210-265, 1981.

Berberian, M. and Walker, R.: The Rudbār Mw earthquake of 1990 June 20; seismotectonics , coseismic and geomorphic displacements, and historic earthquakes of the western "High-Alborz" of Iran, Geophys. J. Int., 182, 1577-1602, doi:10.1111/j.1365246X.2010.04705.x, 2010.

Berberian, M. and Yeats, R. S.: Patterns of historical rupture in the Iranian Plateau, Bull. Seismol. Soc. Am., 89, 120-139, 1999.

Berberian, M. and Yeats, R.S.: Contribution of archaeological data to studies of earthquake history in the Iranian Plateau, J. Struct. Geol., 23, 563-583, 2001. 
Berberian, M., Qorashi, M., Jackson, J., Priestley, K., and Wallace, T.: The Rudbar-Tarom earthquake of 20 June 1990 in NSW Persia - preliminary field and seismological observations and its tectonic significance, Bull. Seismol. Soc. Am, 82, 1726-1755, 1992.

Berberian, M., Malek Shahmirzadi, S., Nokandeh, J., and Djamali, M.: Archaeoseismicity and environmental crises at the Sialk Mounds, Central Iranian Plateau, since the Early Neolithic, J. Archaeol. Sci., 39, 2845-2858, 2012.

Birstein, Y. A., Vinogradova, Y. A., Kondakova, L. G., Kun, M. S., Astakchova, T. V., and Romanova, N. N.: Atlas of the Invertebrates of the Caspian Sea, Izvestiya Pischevaya Promyshlennost, Moscow, 415 pp., 1968.

Boomer, I., Wünnemann, B., Mackay, A. W., Austin, P., Sorrel, P., Reinhardt, C., Keyser, D., Guichard, F., and Fontugne, M.: Advances in understanding the late Holocene history of the Aral Sea region, Quaternary Int., 194, 79-90, 2009.

Brown, N.: History and climate change. A Eurocenter perspective, Routledge, New York, 2001.

Brückner, E.: Klima-Schwankungen seit 1700: nebst Bemerkungen über die Klimaschwankungen der Diluvialzeit, E. Hölzel, 1890.

Dearing, J. A.: Environmental magnetic susceptibility using the Bartington MS2 system, 1999.

Djamour, Y., Vernant, P., Bayer, R., Nankali, H. R., Ritz, J. F., Hinderer, J., Hatam, Y., Luck, B., Le Moigne, N., and Sedighi, M.: GPS and gravity constraints on continental deformation in the Alborz mountain range, Iran, Geophys. J. Int., 183, 1287-1301, 2010.

Dolukhanov, P. M., Chepalyga, A. L., and Lavrentiev, N. V.: The Khvalynian transgressions and early human settlement in the Caspian basin, Quaternary Int., 225, 152-159, 2010.

Dotsenko, S. F., Kuzin, I., Levin, B. V., and Solovieva, O. N.: Tsunami in the CS: Historical events, regional seismicity and numerical modeling, Apetropavlovsk-Kamchatsky Tsunami Workshop Russia, 10-15 September, 2002.

Farhād Mirzā, M. t. D.: Safarnameh e Farhād Mirzā, 1292 AH/1875 AD, edited by: Navāb Safā, E., Zavār Publication, Tehran, Iran, 1987.

Fedchina, V. H.: Russian cartographic maps in the 18th to 19th centuries as a source for Aral-Caspian water fluctuations, in: Humidity change in Aral-Caspian region during the Holocene, edited by: Adrianov, B. V., Zorin, L. B., and Nikolaeva, R. V., USSR, Academy of Science, Institute of water problem, NAUKA, Moscow, 1980.

Gegelyantz, A. A., Galperin, E. N., Kosminskaya, I. P., and Krafshina, R. M.: Structure of the earth's crust in the central part of the Caspian Sea from deep seismic sounding data, Dokl. Akad. Nauk, SSSR, 123, 520-522, 1958.

Gilbert, M.: Imperial Russian History Atlas, Routledge \& Kegan Paul, London, 1978.

Gümilev, N.: Where Was She, the Country of Khazaria?, Nedelja, 24, 7-13, 1964.

Gümilev, N.: History of the Caspian sea level changes during the last 2000 years, in: Humidity change in Aral-Caspian region during the Holocene, edited by: Adrianov, B. V., Zorin, L. B., and Nikolaeva, R. V., USSR, Academy of Science, Institute of water problem, NAUKA, Moskow, 1980.

Hedin, S.: Der Demavand nach eigener Beobachtung, Verhandlung der Ges. Fur Erdkd. Zu Berlin, 19, 304, 1892.
Heiri, O., Lotter, A. F., and Lemcke, G.: Loss on ignition as a method for estimating organic and carbonate content in sediments: reproducibility and comparability of results, J. Paleolimnol., 25, 101-110, 2001.

Hoogendoorn, R. M., Boels, J. F., Kroonenberg, S. B., Simmons, M. D., Aliyeva, E., Babazadeh, A. D., and Huseynov, D.: Development of the Kura delta, Azerbaijan; a record of Holocene Caspian sea level changes, Mar. Geol., 222-223, 359-380, 2005.

Hudud al-Ālam: Hudud al- 'Alam "The regions of the world": a Persian geography, 372 AH/982 AD, edited by: Tehrani, S. J., Majles Publication, Tehran, Iran, 1973.

Ibn Hawqal, M. B. A.: Kitāb șurat al-ard, 366 AH/977 AD, Translated from Arabic by: Sho'ar, J., 2 Ed., Amir Kabir Publication, 400 pp., 1988.

Ibrayev, R. A., Özsoy, E., Schrum, C., and Sur, H. I.: Seasonal variability of the Caspian Sea three-dimensional circulation, sea level and air-sea interaction, Ocean Sci., 6, 311-329, 2010, http://www.ocean-sci.net/6/311/2010/.

Jackson, J., Priestley, K., Allen, M., and Berberian, M.: Active tectonics of the South Caspian Basin, Geophys. J. Int., 148, 214 245, 2002.

Jayhāni, M. B. A.: Al Masālik w- al-Mamālik (Ashkāl al Ālam), 279-294 AH /893-907AD, edited by: Kateb, A. B. A., Āstān Ghods Razavi Publication, Mashhad, Iran, 1989.

Jovayni, A.-M.: Ta'rīkh-i jahān-gushā, 658 AH/1260 AD, edited by: Qazvini, M. A., Arghavān Publication, Tehran, Iran, 1911.

Kakroodi, A. A.: Rapid Caspian Sea-level change and its impact on Iranian coasts, PhD, Department of Geotechnology, Faculty of Civil Engineering and Geosciences, Delft, Netherlands, 121 pp., 2012.

Kakroodi, A. A., Kroonenberg, S. B., Hoogendoorn, R. M., Mohammd Khani, H., Yamani, M., Ghassemi, M. R., and Lahijani, H. A. K.: Rapid Holocene sea level changes along the Iranian Caspian coast, Quaternary Int., 263, 93-103, 2012.

Karpychev, Y. A.: Reconstruction of Caspian Sea level fluctuations: Radiocarbon dating coastal and bottom deposits, Radiocarbon, 35, 409-420, 1993.

Karpychev, Y. A.: Dating of Regressive Stages in the Caspian Sea Using 14C, Vodn. Resur., 25, 274-278, 1998.

Karpychev, Y. A.: Variation in the Caspian Sea level in the Historic Epoch, Water Resour., 1, 1-14, 2001.

Kazanc1, N., Gulbabazadeh, T., Leroy, S. A. G., and Ileri, O.: Sedimentology and environmental characteristics at the GilānMazenderan plain, northern Iran; influence of long and shortterm Caspian level fluctuations on geomorphology, J. Mar. Syst., 46, 154-168, 2004.

Kazin, E. A.: Chronology in the Caucasian mineral water and Stavropol plateau, Bull. of Caucasian Seismic Stations, Tbilisi, July-December 1973, 1974.

Knapp, C. C., Knapp, J. H., and Connor, J. A.: Crustal-scale structure of the South Caspian basin revealed by deep seismic profiling, Mar. Petrol. Geol., 21, 1073-1081, 2004.

Komarova, N. G.: Caspian sea level changes in the Holocene based on historical data, in: Humidity change in Aral-Caspian region during the Holocene, edited by: Adrianov, B. V., Zorin, L. B., and Nikolaeva, R. V., USSR, Academy of Science, Institute of water problem, NAUKA Moskow, 1980.

Kondorskaya, N. and Shebalin, N.: New Catalog of Strong Earthquakes in the Territory of the USSR from Ancient Times to 1975, 
Academy of Sciences, Moscow (English translation, updated through 1977, available as Report SE-31, World Data Center A for Solid Earth Geophysics, Boulder, CO, 606 pp.), 1977.

Kousari, S.: Evolution of Sefidrud Delta, Development in Geological Education, 1, 1986.

Kroonenberg, S. B., Badyukova, E. N., Storms, J. E. A., Ignatov, E. I., and Kasimov, N. S.: A full sea level cycle in 65 years: barrier dynamics along Caspian shores, Sediment. Geol., 134, 257-274, 2000.

Kroonenberg, S. B., Abdurakhmanov, G. M., Aliyeva, E. G., Badyukova, E. N., van der Borg, K., Hoogendoorn, R. M., Huseynov, D., Kalashnikov, A., Kasimov, N. S., Rychagov, G. I., Svitoch, A. A., Vonhof, H. B., and Wesselingh, F. P.: Solarforced $2600 \mathrm{BP}$ and Little Ice Age high-stands of the CS, Quaternary Int., 173-174, 137-143, 2007.

Kuzmin, Y. V., Nevesskaya, L. A., Krivonogov, S. K., and Burr, G. S.: Apparent 14C ages of the "pre-bomb" shells and correction values $(\mathrm{R}, \Delta \mathrm{R})$ for Caspian and Aral Seas (Central Asia), Nuc. Instrum. Method. Phys. Res., 259, 463-466, 2007.

Lahijani, H. and Tavakoli, V.: Identifying provenance of South Caspian coastal sediments using mineral distribution pattern, Quaternary Int., 261, 128-137, 2012.

Lahijani, H. A. K., Tavakoli, V., and Amini, A. H.: South Caspian river mouth configuration under human impact and sea level fluctuations, Environ. Sci., 5, 65-86, 2008.

Lahijani, H. A. K., Rahimpour-Bonab, H., Tavakoli, V., and Hosseindoost, M.: Evidence for Late Holocene high-stands in Central Gilān-East Mazanderan, South Caspian coast, Iran, Quaternary Int., 197, 55-71, 2009.

Leroy, S. A. G., Marret, F., Giralt, S., and Bulatov, S. A.: Natural and anthropogenic rapid changes in the Kara-Bogaz Gol over the last two centuries reconstructed from palynological analyses and a comparison to instrumental records, Quaternary Int., 150, 5270, 2006.

Leroy, S. A. G., Marret, F., Gibert, E., Chalié, F., Reyss, J. L., and Arpe, K.: River inflow and salinity changes in the Caspian Sea during the last 5500 years, Quaternary Sci. Rev., 26, 3359-3383, 2007.

Leroy, S. A. G., Lahijani, H. A. K., Djamali, M., Naqinezhad, A., Moghadam, M. V., Arpe, K., Shah-Hosseini, M., Hosseindoust, M., Miller, C. S., Tavakoli, V., Habibi, P., and Naderi, M.: Late Little Ice Age palaeoenvironmental records from the Anzali and Amirkola lagoons (south CS): vegetation and sea level changes, Palaeogeogr. Palaeocli., 302, 415-434, 2011.

Leroy, S. A. G., Kakroodi, A. A., Kroonenberg, S. B., Lahijani, H. A. K., Alimohammadian, H., and Nigarov, A.: Holocene vegetation history and sea level changes in the SE corner of the Caspian Sea: relevance to SW Asia climate, Quaternary Sci. Rev., 70, 28 47, 2013.

Létolle, R.: Histoire de l'Ouzboï, cours fossile de l'Amou Daria: synthèse et éléments nouveaux Studia Iranica, 29, 195-240, 2000.

Magny, M., Peyron, O., Gauthier, E., Vannière, B., Millet, L., and Vermot-Desroches, B.: Quantitative estimates of temperature and precipitation changes over the last millennium from pollen and lake-level data at Lake Joux, Swiss Jura Mountains, Quaternary Res., 75, 45-54, 2011.

Mamedov, A. V.: The late Pleistocene-Holocene history of the CS, Quaternary Int., 41-42, 161-166, 1997.
Mangino, S. and Priestley, K.: The crustal structure of the southern Caspian region, Geophys. J. Int., 133, 630-648, 1998.

Mar'ashi, Z.: Tārikh e Tabarestān va Rūyān va Māzandarān, 880 AH/1476 AD, edited by: Tasbihi, M., Shargh Publication, Tehran, Iran, 1982.

Mayewski, P. A., Rohling, E. E., Curt Stager, J., Karlén, W., Maasch, K. A., Meeker, L. D., Meyerson, E. A., Gasse, F., van Kreveld, S., Holmgren, K., Lee-Thorp, J., Rosqvist, G., Rack, F., Staubwasser, M., Schneider, R. R., and Steig, E. J.: Holocene climate variability, Quaternary Res., 62, 243-255, 2004.

Mostowfi, H.: Noz'hat al-Gholub, 740 AH/1340 AD, edited by: Siaghi, M. D., Tāhā Publication, Qazvin, Iran, 1999.

Musketov, I. and Orlov, A.: The Catalog of Earthquakes in the Russian Empire, Russ. Geogr. Soc., St. Petersburg, 1893.

Naderi Beni, A., Lahijani, H., Moussavi Harami, R., Leroy, S. A. G., Shah-hosseini, M., Kabiri, K., and Tavakoli, V.: Development of spit-lagoon complexes in response to Little Ice Age rapid sea level changes in the central Gilān coast, South CS, Iran, Geomorphology, 187, 11-26, 2013.

Nahchiri, A.: Joghrafiāy e Tārikhi e Shahrhā (Historical geography of cities), Madreseh Publication, Tehran, Iran, 1999.

Nikitin, P. N.: On the problem of seismic activity in the Caspian Sea and its northwestern coast, Materials of the National Conference on the Problem of the Caspian Sea, Baku, 1963.

Nikitin, P. N.: Chronology of local earthquakes in the northern Caucasus, Pyatigorsk, 1974.

Okhravi, R. and Djamali, M.: The missing ancient Lake of Saveh; a historical review, Iran. Antiq., 38, 327-344, 2003.

Olsson, I. U.: Content of ${ }^{14} \mathrm{C}$ in marine mammals from northern Europe, Radiocarbon, 22, 662-675, 1980

Ozyavas, A., Khan, S. D., and Casey, J. F.: A possible connection of Caspian Sea level fluctuations with meteorological factors and seismicity, Earth Planet. Sci. Lett., 299, 150-158, 2010.

Parodi, S.: Cose e parole nei Viaggi di Pietro della Valle, Accademia della Crusca, 1997.

Pierret, M. C., Chabaux, F., Leroy, S. A. G., and Causse, C.: A record of Late Quaternary continental weathering in the sediment of the Caspian Sea: evidence from U-Th, Sr isotopes, trace element and palynological data, Quaternary Sci. Rev., 51, 40-55, 2012.

Priestley, K., Baker, C., and Jackson, J.: Implications of earthquake focal mechanism data for the active tectonics of the South Caspian Basin and surrounding regions, Geophys. J. Int., 118, 111-141, 1994.

Rabino, H. L.: Les provinces caspiennes de la Perse: Le Guîlân. Illustrations, E. Leroux, 1917.

Rabino, H. L.: Mazandaran and Astarabad, Indus Publications, 1980.

Reimer, P. J., Baillie, M. G. L., Bard, E., Bayliss, A., Beck, J. W., Blackwell, P. G., Ramsey, C. B., Buck, C. E., Burr, G. S., and Edwards, R. L.: IntCal09 and Marine09 radiocarbon age calibration curves, 0-50,000 years cal BP, Radiocarbon, 51, 1111-1150, 2009.

Rekavandi, H. O., Sauer, E. W., Wilkinson, T., Tamak, E. S., Ainslie, R., Mahmoudi, M., Griffiths, S., Ershadi, M., Van Rensburg, J. J., and Fattahi, M.: An imperial frontier of the Sasanian Empire: further fieldwork at the great wall of Gorgan, Iran, 95136, 2007. 
Rodkin, M.: Hydroseismicity, New evidence, J. Geodynamics 15, 247-260, 1992a.

Rodkin, N. V.: Possible correlation of Caspian sea level fluctuations with seismicity, Izvestiya, Earth Sci., 28, 542-549, 1992 b.

Ruddiman, W. F.: Earth Climate, Past and Future, W. H. Freeman and Company, New York, 2008.

Rychagov, G. I.: Holocene oscillations of the Caspian Sea and forecasts based on paleogeographical reconstructions, Quaternary Int., 41-42, 167-172, 1997.

Shah-hosseini, M., Morhange, C., Naderi Beni, A., Marriner, N., Lahijani, H., Hamzeh, M., and Sabatier, F.: Coastal boulders as evidence for high-energy waves on the Iranian coast of Makran, Mar. Geol., 290, 17-28, 2011.

Shilo, N. A. and Krivoshey, M. I.: Relation between the Caspian Sea level variations and strain in the Earth's crust, Vestnik Russ. Acad. Sci., Moscow, 83-90, 1989.

Sorrel, P., Popescu, S. M., Head, M. J., Suc, J. P., Klotz, S., and Oberhansli, H.: Hydrographic development of the Aral Sea during the last 2000 years based on a quantitative analysis of dinoflagellate cysts, Palaeogeogr. Palaeocli., 234, 304-327, 2006.
Storms, J. E. A. and Kroonenberg, S. B.: The impact of rapid sea level changes on recent Azerbaijan ridges, J. Coast. Res., 23, 521-527, 2007.

Stuiver, M. and Reimer, P. J.: Extended C-14 Data-Base and Revised Calib 3.0 C-14 Age Calibration Program, Radiocarbon, 35, 215-230, 1993.

Tusi, S. A.-D. M. B. M. A.: 'Ajā'eb al-Makhluqāt va Ghara'eb alMojudat, 555 AH/1160 AD, edited by: Sotudeh, M., Bongāh-e Tarjomeh va Nashr-e Ketāb, Tehran, 1966.

Ulomov, V. I.: A three-dimensional model of the lithosphere dynamics, seismicity structure, and variations in the Caspian sea level, Izvestiya Phys. Solid Earth, 39, 353-364, 2003.

Varushchenko, S., Varushchenko, A., and Klige, R.: Changes in the regime of the Caspian Sea and closed basins in time, Nauka, Moscow, 1987.

Voropaev, G. V., Krasnozhon, G. F., and Lahijani, H.: Caspian river deltas, Caspia Bulletin, 1, 23-27, 1998.

Walker, M. J. C.: Quaternary dating methods, John Wiley and Son, Chichester, UK, 2005. 